\title{
Studium rozwoju mikroenergetyki w podregionie siedleckim oraz mikroelektroenergetyki w innych podregionach województwa mazowieckiego
}

\section{Zbigniew Cieszkowski}

\section{STRESZCZENIE}

W artykule przedstawiono rzeczowe efekty energetycznego wykorzystania zasobów OZE w segmencie mikroenergetyki elektroenergetycznej i cieplnej w wybranym do szczegółowych badań i analiz podregionie siedleckim, który obejmuje 52 gminy, czyli 16,5\% ogółu gmin województwa mazowieckiego. Zbadano wpływ, jaki na rozwój mikroenergetyki (w tym prosumenckiej) wywarły krajowe uwarunkowania prawne, ustawowy system wsparcia, a także działania planistyczne oraz organizacyjne samorządu województwa i samorządów gmin. Do analiz na poziomie badanego podregionu wykorzystano szczegółowe dane uzyskane z przeprowadzonej ankietyzacji wszystkich jego gmin oraz dane uzyskane od przedsiębiorstw energetycznych i GUS. Przeanalizowano podstawowe uwarunkowania lokalne, w tym ekonomiczne (dochody gmin), techniczne (profile energetyczne gmin, stan sieci dystrybucyjnych), budowlane oraz środowiskowe. Zaakcentowano liczne uwarunkowania pozytywnie wpływające na rozwój segmentu, ale też wyraźnie wskazano na realne ograniczenia. W chwili obecnej brak jest jeszcze specjalistycznych, zilustrowanych konkretnymi danymi, wskaźnikami liczbowymi publikacji branżowych, dotyczących praktycznych efektów rozwoju segmentu mikroenergetyki na poziomie gmin województwa mazowieckiego. Niniejszy artykuł ma za zadanie wypełnienie tego braku, przy czym w odniesieniu do innych niż siedlecki podregionów województwa istniała możliwość przeprowadzenia na podstawie istniejących danych jedynie wstępnej analizy szacunkowej i to tylko w segmencie mikroelektroenergetyki. Na bazie przeprowadzonych analiz oraz najnowszych działań legislacyjnych oraz organizacyjnych rządu, zmierzających do ułatwienia rozwoju mikroenergetyki prosumenckiej, podjęto autorską próbę przedstawienia prognozy udziału tego segmentu elektroenergetyki w udziale województwa mazowieckiego w wypełnieniu krajowych celów wykorzystania OZE w perspektywie lat 2020-2030.

Słowa kluczowe: odnawialne źródła energii (OZE), prosument, polityka klimatyczno-energetyczna, mikroinstalacja, instalacja fotowoltaiczna, kolektor słoneczny, pompa ciepła

\section{Wstęp}

Do najważniejszych celów polskiej transformacji energetycznej, założonych do osiągnięcia również za pomocą rozwoju mikroenergetyki w segmencie prosumenckim należą: udział $\mathrm{w}$ realizacji celów unijnych w zakresie udziału energii z OZE w ogólnym zużyciu energii, wzmacnianie bezpieczeństwa energetycznego (zwłaszcza w wymiarze lokalnym), zmniejszenie zależności energetycznej od dostaw energii z krajowego systemu 
energetycznego, poprawa parametrów technicznych i niezawodności dostaw energii, wzrost konkurencji na rynku energii i uspołecznienie tego rynku, wzrost efektywności wykorzystania energii (ograniczenie strat sieciowych),poprawa stanu środowiska, wykorzystywanie lokalnie dostępnych zasobów OZE, rozwój innowacyjnych rozwiązań technologicznych (inteligentne sieci), tworzenie lokalnych miejsc pracy oraz pobudzenie rozwoju gospodarczego terenów wiejskich. Jak więc widać, mikroenergetyka otrzymała istotną rolę w dziedzinie lokalnego zaopatrzenia w energię elektryczna, a także ciepło. Głównym założeniem idei prosumeryzmu jest produkcja energii i w miarę rozwoju technologii magazynowanie jej w celu późniejszego zużywania, przede wszystkim na własne potrzeby prosumenta, jednak zapisy ustawowe dopuszczają wprowadzenie nadwyżek wyprodukowanej energii do sieci dystrybucyjnej i bezgotówkowe rozliczenie bilansu energii pobranej z sieci i do niej wprowadzonej.

Z uwagi na kilkuletni już okres rozwoju wyodrębnionego prawnie segmentu mikroinstalacji, w tym mających status prosumenckich, autor podjął próbę realizacji wstępnego, pilotażowego programu badawczego obejmującego uzyskane w tym segmencie efekty rzeczowe. Jako obszar szczegółowych badań przyjęto wszystkie (w liczbie 52) gminy podregionu siedleckiego [Cieszkowski 2019], który jest podregionem statystycznym NUTS 3 (poziom trzeci w Nomenklaturze Jednostek Terytorialnych do Celów Statystycznych), obejmującym powiaty: m. Siedlce, siedlecki, garwoliński, łosicki, węgrowski i sokołowski, dla których zgromadzono największą bazę danych. W celu uzyskania niezbędnych i aktualnych informacji o mikroenergetyce lokalnej, wystąpiono do wszystkich gmin podregionu z prośbąo wypełnienie kwestionariuszy, w których zawarto szereg szczegółowych pytań. Dotyczyły one: liczby i mocy wykonanych i planowanych mikroinstalacji do produkcji energii elektrycznej i ciepła w rozbiciu na lokalizacje na obiektach użyteczności publicznej oraz budynkach mieszkalnych, wykorzystanych technologii wytwarzania energii zOZE, wykorzystanych programów wsparcia ekonomicznego, wykonanych dokumentów planowania energetycznego, programów ochrony środowiska, przeprowadzonych akcji informacyjnych i edukacyjnych dla mieszkańców gmin. Zapytano też o problemy, jakie samorządy gminne napotykają w realizacji lokalnej polityki energetyczno-środowiskowej. Następną corocznie aktualizowaną bazę danych dotyczących źródeł OZE przyłączonych do sieci elektroenergetycznych uzyskano w ramach współpracy z operatorami elektroenergetycznych systemów dystrybucyjnych działających na terenie województwa mazowieckiego.

Podstawowymi celami przeprowadzonych badań są:

- określenie efektów rozwoju segmentu mikroenergetyki na poziomie gminnym w odniesieniu do wybranego do szczegółowych analiz podregionu siedleckiego, a także ogólnego stopnia rozwoju mikroelektroenergetyki w pozostałych podregionach województwa mazowieckiego,

- zidentyfikowanie podstawowych mechanizmów i uwarunkowań wpływających na rozwój tego segmentu,

- $\quad$ autorska ocena perspektyw rozwoju mikroenergetyki w świetle zidentyfikowanych uwarunkowań rozwojowych, w tym najnowszych działań legislacyjnych ustawodawcy oraz programów pomocowych rządu. 
Harmonogram prac badawczo-analitycznych obejmował kilka etapów, z których najważniejsze to:

- charakterystyka ustawowej i energetycznej roli oraz zadań segmentu mikroinstalacji w systemie energetycznym kraju wraz z oceną dotychczasowych prognoz rozwoju rynku mikroinstalacji prosumenckich w Polsce oraz z odniesieniem do województwa mazowieckiego i podregionu siedleckiego,

- wpływ lokalnych uwarunkowań infrastrukturalnych (stan sieci dystrybucyjnych, profile energetyczne gmin i odbiorców energii) na efekty rozwoju segmentu,

- szczegółowa ocena stopnia rozwoju w gminach podregionu siedleckiego mikroenergetyki wykorzystującej OZE do wytwarzania energii elektrycznej niskiego napięcia (stosowany powszechnie skrót - nN) i ciepła, obejmująca określenie oraz branżową interpretację kilku podstawowych wskaźników procentowych ilustrujących uzyskane efekty rzeczowe,

- ocena aktywności inwestycyjnej gmin podregionu siedleckiego na tle uwarunkowań prawnych, systemu wsparcia organizacyjnego i ekonomicznego, programów realizowanych we współpracy z samorządem województwa mazowieckiego, dochodów własnych gmin,

- ogólna, wstępna ocena stopnia rozwoju mikroelektroenergetyki w pozostałych podregionach województwa mazowieckiego,

- $\quad$ podsumowanie, w tym ocena aktualnego stopnia rozwoju segmentu mikroenergetyki $\mathrm{w}$ podregionie siedleckim i pozostałych podregionach regionu oraz perspektyw rozwojowych w latach 2020-2030 w świetle aktualnej polityki środowiskowoenergetycznej rządu i uwarunkowań infrastrukturalnych.

Z uwagi na fakt, iż w praktyce segment mikroenergetyki elektroenergetycznej służy lokalnemu zaopatrzeniu w energię elektryczną niskiego napięcia, podstawowe wskaźniki rozwoju segmentu odnoszono jedynie do tego napięcia. Tematyka związana z produkcją oraz zużyciem energii elektrycznej (w tym z OZE) na poziomie napięć średnich, wysokich i najwyższych nie wchodzi w zakres niniejszego opracowania.

\section{Prawne i ekonomiczne uwarunkowania rozwoju segmentu mikroenergetyki}

Za usankcjonowany prawnie początek powstania w Polsce segmentu mikroenergetyki OZE uznać należy rok 2013, w którym po raz pierwszy w krajowym ustawodawstwie dotyczącym rynku energetycznego pojawiła się w ustawie z dnia 26 lipca 2013 r. o zmianie ustawy dnia 10 kwietnia 1997 r. - Prawo energetyczne oraz niektórych innych ustaw prawna definicja mikroinstalacji oraz specjalnie przeznaczony temu segmentowi system wsparcia organizacyjnego i ekonomicznego.

W ustawie z dnia 7 czerwca 2018 r. o zmianie ustawy o odnawialnych źródłach energii oraz niektórych innych ustaw (Dz.U. z 2018 r. poz. 1276) dokonano rozszerzenia granicznych parametrów energetycznych segmentu, wobec czego aktualna definicja brzmi: 
mikroinstalacja - instalacja odnawialnego źródła energii o łącznej mocy zainstalowanej elektrycznej nie większej niż $50 \mathrm{~kW}$, przyłaczona do siecielektroenergetycznej o napięciu znamionowym niższym niż 110 kV albo o mocy osiagalnej cieplnej w skojarzeniu nie większej niż 150 kW, w której taczna moc zainstalowana elektryczna jest nie większa niż $50 \mathrm{~kW}$.

W ustawie z dnia 22 czerwca 2016 r. o zmianie ustawy o odnawialnych źródłach energii oraz niektórych innych ustaw (Dz.U. z 2016 r. poz. 925) ustawowo wprowadzono definicję prosumenta, a w kolejnej ustawie z dnia 7 czerwca 2018 r. o zmianie ustawy o odnawialnych źródłach energii oraz niektórych innych ustaw (Dz.U. z 2018 r. poz. 1276) skorygowano ją do postaci:

prosument - odbiorca końcowy dokonujacy zakupu energii elektrycznej na podstawie umowy kompleksowej, wytwarzajacego energię elektryczna wyłacznie z odnawialnych źródeł energii $w$ mikroinstalacji w celu jej zużycia na potrzeby własne, niezwiazane z wykonywana działalnościa gospodarcza regulowana ustawa z dnia 6 marca 2018 r. - Prawo przedsiębiorców.

Aby mieć status prosumenta i korzystać z przypisanego systemu rozliczeń wprowadzanych do sieci nadwyżek wytworzonej w mikroźródle energii elektrycznej, odbiorca i jednocześnie wytwórca energii musiał, zgodnie z tym zapisem, spełniać szereg wymogów prawnych i technicznych. Ustawodawca zaliczył do nich konieczność wytwarzania energii elektrycznej na własne potrzeby w mikroinstalacji OZE przez odbiorcę niebędącego przedsiębiorca, który ma podpisaną z przedsiębiorstwem energetycznym umowę kompleksową na odbiór energii i usługę dystrybucyjną. Mikrowytwórca, który nie spełnia powyższych wymogów, nie był prosumentem w sensie ustawowym, aczkolwiek w sensie technicznym można go było tak określić, był on bowiem jednocześnie konsumentem i wytwórca energii, a termin prosument wywodzi się z połącznia sylab: pro od producenta i sument do konsumenta.

Prowadzona powszechnie krytyka praktycznych aspektów funkcjonowania systemu prosumenckiego oraz realne zagrożenie nie osiagnięcia przez Polskę w perspektywie $2020 \mathrm{r}$. 15\% udziału energii z OZE w ogólnym zużyciu energii, skłoniło rząd do opracowania i ogłoszenia w styczniu 2019 r. szerokiego, zawierającego szereg rozwiązań prawnych i ekonomicznych programu pod nazwą Energia Plus. W jego ramach opracowano również istotną korektę ustawy o OZE, która włączy w system prosumencki sektor małych i średnich przedsiębiorstw, a także spółdzielnie energetyczne. Przyjęta przez Sejm w dniu 19 lipca 2019 r. ustawa z dnia 19 lipca 2019 r. o zmianie ustawy o odnawialnych źródłach energii oraz niektórych innych ustaw, (Dz.U. z 2019 r. poz. 1524) formułuje definicję:

prosument energii odnawialnej - odbiorca końcowy wytwarzajacy energie elektryczna wyłacznie z odnawialnych źródet energii na własne potrzeby w mikroinstalacji, pod warunkiem, że w przypadku odbiorcy końcowego niebędacego odbiorca energii elektrycznej w gospodarstwie domowym, nie stanowi to przedmiotu przeważającej działalności gospodarczej określonej zgodnie z przepisami wydanymi na podstawie art. 40 ust. 2 ustawy z dnia 29 czerwca 1995 r. o statystyce publicznej (Dz.U. z 2019 r. poz. 649 i 730).

Zgodnie z zapisami znowelizowanej ustawy prosument może magazynować wytworzoną energię oraz sprzedawaćją nie tylko sprzedawcy zobowiązanemu na określonych warunkach, ale także dowolnemu innemu sprzedawcy na warunkach z nim uzgodnionych. 
Wytwórca mający prawny status prosumenta korzysta z uproszczonej 30-dniowej procedury przyłączenia do sieci, jeśli oprócz ww. wymogów moc elektryczna zgłoszonej do przyłączenia mikroinstalacji wytwórczej jest nie większa niż moc określona w warunkach technicznych przyłączenia instalacji odbiorczej. Koszt montażu układu zabezpieczeń instalacji wytwórczej i układu pomiarowo-rozliczeniowego w przypadku mikroinstalacji ponosi operator sieci dystrybucyjnych. Prosument zwolniony jest też w określonym zakresie z niektórych opłat rozliczeniowych i dystrybucyjnych. Wytwórca energii, który nie mieści się w ramach wymagań systemu prosumenckiego zawiera umowę o przyłączenie instalacji wytwórczej do sieci na zasadach ogólnych, jest to jednak procedura znacznie dłuższa i bardziej skomplikowana.

Energia elektryczna wytworzona $\mathrm{w}$ instalacji prosumenta i wprowadzona do sieci dystrybucyjnej zbilansowana zostaje $\mathrm{z}$ energią pobraną z sieci, a rozliczenie odbywa się z zastosowaniem współczynników uzależnionych od mocy zainstalowanej w danym urządzeniu wytwórczym. I tak, dla instalacji do $10 \mathrm{~kW}$ włącznie jest to stosunek 1 do 0,8, czyli dla energii wprowadzonej do sieci wytwórca może odebrać sobie bezpłatnie $80 \%$ tego wolumenu w okresie, kiedy pobiera energię z sieci. Dla instalacji powyżej $10 \mathrm{~kW}$ stosunek ten kształtuje się na poziomie 1 do 0,7. Przedsiębiorstwo obrotu energią otrzymuje nieodpłatnie pozostałe $20 \%$ lub 30\% w ramach tzw. opustu, stąd zastosowany bezgotówkowy system rozliczeń nazywany bywa potocznie systemem opustów, w którym to producent energii udziela opustu przedsiębiorstwu energetycznemu darując mu faktycznie pewien wolumen energii. Omawiana zmiana ustawy zakłada, że w stosunku do spółdzielni energetycznych rozliczenie pobranej z sieci i wprowadzonej do niej energii, następować będzie ze współczynnikiem 1 do 0,6.

Zdaniem autora niniejszego opracowania, termin opust jest nieadekwatny do stanu rzeczywistego, albowiem powyższy wolumen nie jest dobrowolną darowizną mikrowytwórcy energii na rzecz przedsiębiorstwa energetycznego, lecz swego rodzaju wymuszonym prawnie udziałem partycypacyjnym prosumenta w kosztach przyłączenia i obsługi technicznej systemu dystrybucji i obrotu energią. Bardzo istotnym wnioskiem praktycznym wynikającym z powyższego systemu rozliczeń jest konieczność dopasowania mocy elektrycznej planowanych do zainstalowania mikroinstalacji do rocznego zapotrzebowania na energię elektryczna, w celu minimalizacji nadwyżki nieskonsumowanej energii wyprowadzanej do sieci.

Niepowodzenia, jakie zanotował rząd w efektach rozwoju wysokoparametrowej energetyki odnawialnej wskutek zachowawczej polityki wobec sektora energetyki węglowej oraz wstrzymania rozwoju energetyki wiatrowej, były powodem opracowania i wdrażania w życie wspomnianego wyżej programu Energia Plus. Ma on być, łącznie z ogłoszonymi w lipcu 2019 r. programami Mój prąd i AgroEnergia, swego rodzaju kołem ratunkowym dla krajowego sektora OZE. Zadaniem programów jest gwałtowne przyspieszenie rozwoju segmentu mikroenergetyki prosumenckiej, który ma odegrać istotną rolę w osiągnięciu przez Polskę w perspektywie 2020 r. 15\% udziału energii z OZE w ogólnym zużyciu energii. 
Tzw. Pakiet prosumencki zawarty w nowelizowanych ustawach (ustawa o OZE, Prawo energetyczne, Prawo budowlane) zawiera szereg ułatwień organizacyjnych, takich jak: włączenie sektora mikro, małych i średnich przedsiębiorców oraz spółdzielni energetycznych w system prosumencki, zwiększenie z roku do dwóch lat okresu rozliczania bilansu energii wyprodukowanej i zużytej przez prosumenta, odstąpienie od obowiązku wykonywania projektów budowlanych dla instalacji o mocy do $6,5 \mathrm{~kW}$, prawne umożliwienie lokalizowania mikroinstalacji na terenach mających w planach miejscowych przeznaczenie inne niż produkcyjne, opracowanie przepisów wykonawczych określających zasady i procedury przyłączania mikroinstalacji do sieci oraz zakres i zasady bilansowania energii i rozliczania jej z prosumentami.

W zakresie wsparcia ekonomicznego, program Energia Plus wprowadził w życie ulgę termomodernizacyjną w podatku dochodowym od osób fizycznych, Ekopożyczkę PKO BP dla gospodarstw domowych, gwarancje kredytowe Biznesmax na instalacje fotowoltaiczne dla firm. Program Mój prąd zakłada w skali kraju wydatkowanie kwoty 1 mld zł na dopłaty z NFOŚiGW do nowych prosumenckich instalacji fotowoltaicznych, wybudowanych przez gospodarstwa domowe. Maksymalne dofinansowanie to 5 tys. zł dla gospodarstwa domowego, które wypłacone zostanie po zakończeniu budowy instalacji o mocy 2-10 kW. Kwota dotacji ma pomóc w instalacji w skali kraju około 200000 instalacji domowych. Całkowity budżet skierowanego do rolników indywidualnych programu AgroEnergia to 200 milionów złotych, z czego 120 mln przeznaczone jest na zwrotne formy finansowania, a $80 \mathrm{mln}$ zł na wsparcie bezzwrotne. Rolnicy mogą otrzymywać wsparcie dla przedsięwzięć z zakresu nowych źródeł ciepła i energii elektrycznej (w tym OZE) oraz magazynów energii.

Kolejną ulgą finansową dla prosumentów jest zmniejszenie z 23\% do 8\% stawki VAT na mikroinstalacje prosumenckie zamontowane poza budynkami mieszkalnymi o powierzchni do $300 \mathrm{~m}^{2}$, lecz dostarczające im energii. Zmiany dokonano w przegłosowanej 11 września 2019 r. przez Sejm ustawie o zmianie ustawy Prawo Ochrony Środowiska.

Według stanu z drugiej połowy 2019 r. rynkowe ceny za 1 kW mocy zainstalowanej w prosumenckich instalacjach fotowoltaicznych kształtują się w okolicach 4-5 tys. zł, codaje 8-10 tys. zł za instalację 2 kW i 200-250 tys. zł za instalację o mocy $50 \mathrm{~kW}$. Zgodnie z dokonaną przez autora wstępną, szacunkową oceną ekonomicznej opłacalności montażu domowych instalacji o najczęściej występujących mocach 3-6 kW, zakładającej wykorzystanie wszystkich z ww. i możliwych do połączenia opcji wsparcia ekonomicznego, okres zwrotu kosztów inwestycyjnych wynosić będzie od 6 do 8 lat. Znacznie krótszy okres zwrotu ma miejsce $\mathrm{w}$ przypadku udziału prosumenta we wdrażanych przez gminy programach inwestycyjnych opartych o wykorzystanie środków unijnych (np. RPOWM), bowiem stopień dofinansowania może osiągnąć tam poziom $80 \%$.

Zdaniem organizacji eksperckich, a także wielu potencjalnych inwestorów indywidualnych, zaproponowane rozszerzenie katalogu prosumentów oraz nowe instrumenty wsparcia organizacyjnego i ekonomicznego (w tym mocno akcentowanego medialnie programu Mój prąd) nie spowodują lawinowego wzrostu liczby mikroinstalacji w segmencie energetyki mikroprosumenckiej, albowiem głównym impulsem do jego rozwoju jest 
opłacalność ekonomiczna inwestycji oparta na obiektywnych zasadach i prawach rządzących rozwojem rynków energii. W przypadku instalacji mikrofotowoltaicznych, ich montaż zacznie się opłacać w Polsce około 2021-2022 r., kiedy to wg prognoz osiągnięty zostanie tzw. stan Grid parity (parytet sieci), czyli sytuacja, w której nowe źródło będzie dostarczać energię elektryczną po koszcie średnim nie większym niż koszt nabycia energii w sieci energetycznej. Osiągnięcie tego stanu da potencjał rozwojowy całemu sektorowi OZE, ale już bez subwencji lub innego wsparcia publicznego.

\section{Prekursorskie koncepcje tworzenia segmentu mikroenergetyki i prognozy rozwoju}

Jako kompleksową i prekursorską prognozę rozwoju segmentu prosumenckiego w Polsce należy uznać Krajowy Plan Rozwoju Mikroinstalacji Odnawialnych Źródeł Energii do roku 2030 opracowany w 2015 r. przez Instytut Energetyki Odnawialnej (IEO). Opracowanie nie ma charakteru oficjalnego dokumentu rządowego, zrealizowano je w ramach kampanii społecznej. Na bazie wszechstronnych analiz ówczesnych uwarunkowań prawnych, dokumentów rządowych, obowiązującego systemu wsparcia sektora OZE, oceny potencjalnych zasobów zielonej energii, zespół autorski przedstawił bardzo ambitną koncepcję rozwoju segmentu mikroenergetyki, jako ważnego elementu polityki energetycznej, środowiskowej, a także społeczno-gospodarczej kraju. Plan zakładał konkretne efekty rzeczowe (moce źródeł energii elektrycznej i cieplnej, wolumeny energii) postulowane do uzyskania w poszczególnych latach, określono również niezbędne nakłady finansowe (środki publiczne) niezbędne do realizacji założonych celów. W opracowaniu omówiono podstawy technologiczne i zasady działania mikroinstalacji (kolektory słoneczne, panele fototowoltaiczne, mikrowiatraki, kotły biomasowe, pompy ciepła, mikrosystemy kogeneracyjne na biogaz i biopłyny) oraz podano ścieżki rozwoju poszczególnych grup tych instalacji.

Zestawienie prognoz IEO w zakresie prognozowanych mocy z rzeczywistymi efektami rozwoju segmentu mikroźródeł energii elektrycznej dla lat 2016-2018 (tabela 1) ilustruje bardzo niski wskaźnik realizacji prognoz. Osiągnął on w skali kraju dla analizowanych lat wartości na poziomie jedynie około 20-26\%, a w odniesieniu do województwa mazowieckiego jeszcze mniej, bo jedynie 6,5-10,8\%. Bardzo niekorzystnie, w porównaniu z prognozami, wypada również realne wykorzystanie technologii - w obszarze wytwarzania energii elektrycznej rozwijają się jedynie instalacje fotowoltaiczne, natomiast wiatraki i instalacje kogeneracyjne na biogaz i biopłyny reprezentowane są w ilościach śladowych. W odniesieniu do mikroźródeł służących wytwarzaniu ciepła właściwie rozwijają się jedynie instalacje solarne i pompy ciepła. W tej grupie stopień realizacji prognoz IEO kształtuje się również na poziomie około $20 \%$.

Opublikowane w 2015 r. opracowanie [Cieszkowski, Girczuk, Polak 2015] prognozowało, że w 2020 r. łączna moc mikroźródeł energii elektrycznej osiągnie w regionie poziom $180 \mathrm{MW}$, natomiast rzeczywista wartość tej mocy wynosiła na 31.12.2018 r. około 37,4 MW o potencjale wytwórczym energii na poziomie około $37000 \mathrm{MWh}$. Zakładając dotychczasową dynamikę 
szacuje się, że na koniec 2020 r. mazowiecki segment mikroenergetyki OZE może dysponować mocą na poziomie $80 \mathrm{MW}$ o zdolności wytwarzania w okolicach $85000 \mathrm{MWh}$, co stanowić będzie jedynie około 44\% dla mocy i 32\% dla energii w odniesieniu do prognoz z $2015 \mathrm{r}$.

Przy ocenie realnych zdolności wytwórczych instalacji wykorzystujących poszczególne technologie OZE określa się wspótczynnik wykorzystania mocy będący stosunkiem rocznego wolumenu energii wytworzonej przez daną instalację do iloczynu jej mocy znamionowej i całkowitego teoretycznego czasu pracy (w skali roku jest 8760 godzin). W polskich warunkach nasłonecznienia, dla pojedynczych mikroinstalacji PV, wartość liczbowa współczynnika zawiera się w przedziale od około 9\% do około 11,5\%.

Tabela 1. Prognozowany a rzeczywisty rozwój mikroźródeł energii elektrycznej z OZE w kraju, województwie mazowieckim i podregionie siedleckim w latach 2016-2018

\begin{tabular}{|c|c|c|c|c|c|c|c|c|c|c|}
\hline \multicolumn{11}{|c|}{ Moce prognozowane i zainstalowane } \\
\hline \multirow{3}{*}{ Lp. } & \multirow{3}{*}{ Rok } & \multicolumn{3}{|c|}{ Polska } & \multicolumn{3}{|c|}{ Województwo mazowieckie } & \multicolumn{3}{|c|}{ Podregion siedlecki } \\
\hline & & 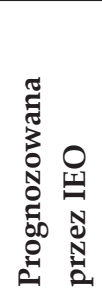 & 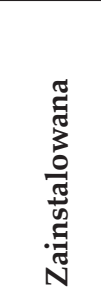 & 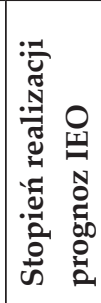 & 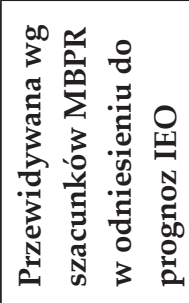 & 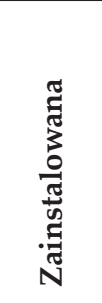 & 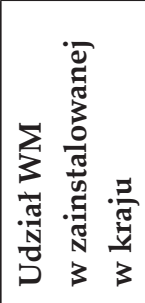 & 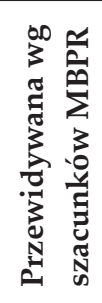 & 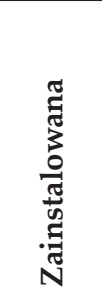 & 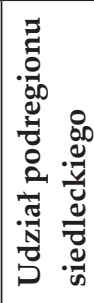 \\
\hline & & [MW] & {$[\mathrm{MW}]$} & $\%$ & {$[\mathrm{MW}]$} & [MW] & $\%$ & [MW] & [MW] & $\%$ \\
\hline 1. & 2016 & 400,0 & 102,3 & 25,6 & 61,6 & 6,6 & 6,5 & 8,6 & 0,7 & 10,8 \\
\hline 2. & 2017 & 900,0 & 183,0 & 20,3 & 138,6 & 16,4 & 9,0 & 19,3 & 1,2 & 7,3 \\
\hline 3. & 2018 & 1500,0 & 346,5 & 23,1 & 231,0 & 37,4 & 10,8 & 32,1 & 3,8 & 10,2 \\
\hline
\end{tabular}

Źródło: opracowanie własne MBPR na podstawie prognoz IEO, danych BDL oraz informacji udzielonych przez gminy i przedsiębiorstwa energetyczne

Jak wykazano, realny rozwój segmentu mikroenergetyki (ale też całego sektora OZE) [Cieszkowski 2018] przebiega w Polsce i województwie znacznie wolniej niż przewidywano $\mathrm{w}$ prognozach opracowanych kilka lat temu. Przeorientowanie w $2015 \mathrm{r}$. polityki rządu na ochronę przemysłu węglowego oraz interesu koncernów zarządzających klasyczną energetyką korporacyjna, zaowocowało praktycznie zahamowaniem rozwoju wysokoparametrowej energetyki odnawialnej oraz opóźnieniem rozwoju segmentu mikroinstalacji energetycznych. 


\section{Infrastrukturalne uwarunkowania rozwoju mikroelektroenergetyki w podregionie siedleckim}

Wśród rozlicznych uwarunkowań rozwoju omawianego segmentu mikroenergetyki, najmniej zdiagnozowane, a w konsekwencji jeszcze niedostępne w publikowanych źródłach są lokalne uwarunkowania infrastrukturalne wynikające z podstawowych parametrów technicznych i eksploatacyjnych lokalnych sieci dystrybucyjnych średniego i niskiego napięcia. Wynika to z faktu, że proces rozwoju mikroelektroenergetyki prosumenckiej jest w początkowym stadium, brak jest więc jeszcze doświadczeń praktycznych w planowaniu i przyłączaniu do sieci dużej liczby niestabilnych instalacji wytwórczych. Źródła wytwórcze, nadmiernie skumulowane w lokalnych węzłach sieci, jakimi są poszczególne stacje trafo SN/nN mogą w sposób istotny zakłócać pracę tych węzłów, szczególnie poprzez destrukcję wymaganych przepisami poziomów napięć. Bardzo problematyczne może być również przyłączenie do istniejącej sieci nN nawet pojedynczej mikroinstalacji wytwórczej o mocy od $10 \mathrm{~kW}$ do $50 \mathrm{~kW}$. W celu minimalizacji problemu istnieje potrzeba nawiązania współpracy i wymiany informacji pomiędzy operatorem sieci dystrybucyjnych a gmina, która przystępuje do realizacji programu budowy na swym terenie znacznej liczby prosumenckich mikroźródeł wytwórczych. Zebrana przez gminę lista mieszkańców chętnych do pozyskania swojego źródła energii winna być zweryfikowana pod kątem planowanego przyłączenia danej liczby i mocy źródeł do poszczególnych jednostek transformatorowych, w celu wcześniejszego podjęcia przez zakład dystrybucyjny koniecznych dla danych fragmentów sieci prac adaptacyjnych. Nałożony prawnie i ostatnio (lipiec 2019) rozszerzony o grupę małych i średnich przedsiębiorstw obowiązek przyłączania do sieci mikroźródeł prosumenckich, nie może być powodem pogarszania się w wyniku realizacji tych przyłączeń parametrów jakościowych energii dostarczanej odbiorcom zlokalizowanym w obszarze oddziaływania przyłączanych instalacji.

Na użytek artykułu sporządzono (tabela 2) podstawowy, ogólny profil energetyczny gmin podregionu siedleckiego oraz statystyczny (tabela 3) profil jednostek sieciowych, na które składają się poszczególne stacje transformatorowe $\mathrm{SN} / \mathrm{nN}$ wraz z zasilanymi z nich liniami nN. Wyliczone wskaźniki techniczne posłużą do próby prekursorskiego, z konieczności uproszczonego i bardzo ogólnego oszacowania sumarycznej możliwości przyłączeniowej sieci dystrybucyjnych funkcjonujących na omawianym obszarze. 
Tabela 2. Profil elektroenergetyczny gmin podregionu siedleckiego wg rodzajów gmin

\begin{tabular}{|l|c|c|c|c|c|}
\hline Rodzaj gminy & $\begin{array}{l}\text { Średnia } \\
\text { moc na } \\
\text { stację trafo } \\
\mathbf{1 5 / 0 , 4}[\mathbf{k V A}]\end{array}$ & $\begin{array}{l}\text { Liczba } \\
\text { odbiorców } \\
\text { na stację }\end{array}$ & $\begin{array}{l}\text { Moc na } \\
\text { odbiorcę }\end{array}$ & $\begin{array}{l}\text { Roczne } \\
\text { zużycie energi } \\
\text { na odbiorce } \\
\text { [kWh] }\end{array}$ & $\begin{array}{l}\text { Min i max } \\
\text { zużycia energii } \\
\text { [kWh] }\end{array}$ \\
\hline Miejskie & 274 & 109 & 2,5 & 3339 & $\begin{array}{c}3020 \text { Siedlce } \\
5118 \text { Łaskarzew }\end{array}$ \\
\hline Miejsko-wiejskie & 120 & 36 & 3,5 & 3160 & $\begin{array}{l}2893 \text { Łochów } \\
3882 \text { Łosice }\end{array}$ \\
\hline Wiejskie & 83 & 28 & 2,9 & 3862 & $\begin{array}{c}2244 \text { Stoczek } \\
5536 \text { Olszanka }\end{array}$ \\
\hline Podregion & 112 & 40 & 2,8 & 3581 & $\begin{array}{c}2244 \text { Stoczek } \\
5536 \text { Olszanka }\end{array}$ \\
\hline
\end{tabular}

Źródło: opracowanie własne MBPR na podstawie danych uzyskanych od PGE Dystrybucja S.A.

Tabela 3. Profil jednostek sieciowych $\mathrm{SN} / \mathrm{nN}$ w gminach powiatu mińskiego i siedleckiego wg roku budowy

\begin{tabular}{|l|l|l|c|c|}
\hline $\begin{array}{l}\text { Lata budowy } \\
\text { sieci - dekady }\end{array}$ & $\begin{array}{l}\text { Jednostki } \\
\text { sieciowe SN/ } \\
\text { nN w gminach } \\
\text { powiatu } \\
\text { mińskiego [szt] }\end{array}$ & $\begin{array}{l}\text { Jednostki } \\
\text { sieciowe SN/ } \\
\text { nN w gminach } \\
\text { powiatu } \\
\text { siedleckiego [szt] }\end{array}$ & Razem [szt] & $\begin{array}{l}\text { Udział } \\
\text { dekady [\%] }\end{array}$ \\
\hline Przed 1970 & 338 & 154 & 492 & 16,4 \\
\hline 1970-1979 & 324 & 291 & 615 & 20,5 \\
\hline 1980-1989 & 324 & 352 & 676 & 22,6 \\
\hline $1990-1999$ & 196 & 178 & 374 & 12,5 \\
\hline $2000-2009$ & 99 & 172 & 271 & 9,0 \\
\hline $2010-2019$ & 351 & 218 & 569 & 19,0 \\
\hline Razem & 1632 & 1365 & 2997 & 100,00 \\
\hline
\end{tabular}

Źródło: opracowanie własne MBPR na podstawie danych uzyskanych od PGE Dystrybucja S.A.

W procesie diagnozy zdolności przyłączeniowych, fundamentalne znaczenie ma stan techniczny sieci, ich rodzaj oraz układ pracy, stąd konieczność sporządzenia podstawowej, uogólnionej diagnozy lokalnych sieci dystrybucyjnych średniego napięcia (SN) i nN. Oparto ją na badaniach własnych, prowadzonych sukcesywnie w latach 2000-2019 dla powiatu siedleckiego i mińskiego (zlokalizowany poza podregionem siedleckim, lecz reprezentatywny również dla wschodniego Mazowsza) na potrzeby statystycznego profilu struktury wiekowej i cech eksploatacyjnych lokalnych sieci dystrybucyjnych. Profil sporządzony na 
bazie około 3000 jednostek sieciowych jest reprezentatywny również w odniesieniu do sieci dystrybucyjnych SN i nN całego podregionu siedleckiego, dlatego może być wykorzystany na potrzeby niniejszego artykułu. Wniosek taki sformułowano na podstawie doświadczenia oraz wiedzy praktycznej nabytej przez autora w okresie ponad 30-letniej pracy przy planowaniu i projektowaniu rozległych układów sieciowych.

Podstawowym problemem zdecydowanej większości sieci, w tym zwłaszcza wiejskich sieci dystrybucyjnych $\mathrm{SN}$ i $\mathrm{nN}$ jest to, iż zostały zaprojektowane jako urządzenia napowietrzne, przystosowane jedynie do odbioru energii, często ze zbyt małymi wartościami mocy dla poszczególnych grup odbiorców i jak się okazało obecnie, zbyt niskimi współczynnikami jednoczesności [Cieszkowski 2004]. Przy długich obwodach linii nN skutkuje to, w połączeniu z niskimi przekrojami przewodów i zbyt dużymi obciążeniami, istotnym pogorszeniem parametrów energii dostarczanej odbiorcom.

W stosunkowo złym stanie technicznym są sieci najstarsze, wybudowane przed rokiem 1980, które do tej pory nie zostały poddane pełnej modernizacji. Odsetek takich jednostek kształtuje się w podregionie siedleckim na poziomie około $36,9 \%$ co, na ogólną liczbę 4500 pracujących w nim, daje liczbę około 1600 jednostek. Na podstawie analiz własnych, średnia zdolność przyłączeniowa liczby mikroźródeł energii dla statystycznego modelu stacji, niepowodująca istotnych zakłóceń jej pracy kształtuje się na poziomie około 15\% liczby odbiorców do stacji przyłączonych. Statystyczna moc pojedynczego źródła wynosi 4,8 kW (tabela 4), a więc może się okazać, że dla mocy większych (zwłaszcza powyżej $10 \mathrm{~kW}$ ) parametry techniczne niektórych jednostek mogą nie gwarantować bezpiecznego przyłączenia nawet jednego źródła bez wykonania potrzebnej przebudowy lub modernizacji.

Tabela 4. Średnie moce jednostkowe mikroinstalacji OZE zainstalowanych i planowanych w podregionie siedleckim - stan na 31.12.2018 r.

\begin{tabular}{|l|l|l|l|l|l|}
\hline $\begin{array}{l}\text { Rodzaj } \\
\text { mikroinstalacji }\end{array}$ & $\begin{array}{l}\text { Wykonane } \\
\text { na obiektach } \\
\text { użyteczności } \\
\text { publicznej } \\
{[\mathrm{kW}]}\end{array}$ & $\begin{array}{l}\text { Wykonane na } \\
\text { budynkach } \\
\text { mieszkańców } \\
{[\mathrm{kW}]}\end{array}$ & $\begin{array}{l}\text { Planowane } \\
\text { na obiektach } \\
\text { użyteczności } \\
\text { publicznej } \\
{[\mathrm{kW}]}\end{array}$ & $\begin{array}{l}\text { Planowane na } \\
\text { budynkach } \\
\text { mieszkańców } \\
{[\mathrm{kW}]}\end{array}$ & $\begin{array}{l}\text { Wszystkie } \\
\text { wykonane } \\
\text { PV gminne } \\
\text { i indywidualne } \\
\text { razem [kW] }\end{array}$ \\
\hline Fotowoltaiczne & 12,9 & 2,9 & 15,0 & 4,1 & 4,8 \\
\hline
\end{tabular}

Źródło: opracowanie własne MBPR na podstawie danych uzyskanych od PGE Dystrybucja S.A. oraz w badaniu ankietowym gmin

Drugą grupą jednostek sieciowych $(35,1 \%$ z 4500, czyli około 1580) są urządzenia wybudowane w dwudziestoleciu pomiędzy latami 1980 a 2000, których długości obwodów, przekroje przewodów i zastosowane przy projektowaniu parametry obciążeniowe, umożliwiają w ujęciu statystycznym przyłączenie około $25 \%$ (w odniesieniu do liczby przyłączonych odbiorców) mikroźródeł energii. Również i tu zastrzega się, że źródła powyżej $10 \mathrm{~kW}$ wymagają już konkretnych analiz przypadku. 
W stosunkowo najlepszej sytuacji znajdują się jednostki najnowsze, wybudowane lub kompletnie zmodernizowane po 2000 r. Są to już często sieci kablowo-napowietrzne o stosunkowo stabilnych napięciowo parametrach energii, co umożliwia przyłączenie mikroźródeł wytwórczych w granicach nawet 35-40\% liczby odbiorców. Takich jednostek jest w subregionie $28 \%$, czyli około 1260 .

Do niektórych obwodów sieci nN mogą być już przyłączane makrogeneratory o mocach nawet do $50 \mathrm{~kW}$. W przedstawionych analizach nie wyodrębniono osobno miejskich stacji pracujących w pierścieniowych systemach kablowych, bowiem specyfika terenów miejskich, charakter zabudowy stwarzają inny katalog uwarunkowań rozwoju dla segmentu mikroenergetyki.

Na bazie pozyskanych danych i ich analiz, wyliczono szacunkowy wolumen mocy ogólnej mikroinstalacji możliwej do przyłączenia w podregionie siedleckim w aktualnym stanie technicznym pracujących w nim sieci dystrybucyjnych. Dla przyjętej mocy jednostkowej pojedynczej mikroinstalacji wytwórczej wynoszącej 4,83 kW, szacowana zdolność przyłączeniowa wynosi około 43000 źródeł, co po przeliczeniu stanowi około:

- $24 \%$ odbiorców zlokalizowanych w podregionie,

- $\quad 44 \%$ mocy odniesionej do ogólnej mocy czynnej o wartości 467 MW zainstalowanej w transformatorach $\mathrm{SN} / \mathrm{nN}$,

- $\quad 28 \%$ ogólnego zużycia w podregionie energii elektrycznej niskiego napięcia.

Zastrzec jednak należy, że są to jedynie wstępne, hipotetyczne wartości orientacyjne, wymagające dalszych czynności weryfikacyjnych, wykonywanych na uszczegółowionych i cykliczne aktualizowanych bazach danych wykorzystujących praktyczne doświadczenia zakładów dystrybucyjnych w przyłączaniu zespołów mikroinstalacji wytwórczych do konkretnych rodzajów i układów sieciowych.

Również istotnym uwarunkowaniem infrastrukturalnym jest stan techniczny i lokalizacja budynków mieszkalnych i gospodarczych, oceniane pod kątem przydatności do umieszczenia na ich dachach instalacji fotowoltaicznych. Istotne są tu wytrzymałości mechaniczne dachów, rodzaj pokrycia, kąty nachylenia połaci dachowych oraz orientacja w stosunku do kierunków geograficznych, położenie w stosunku do budynków, obiektów sąsiednich i wysokich drzew. $Z$ analiz własnych autora wynika, że dobre lub bardzo dobre uwarunkowania budowlane i środowiskowe posiada około 20-25\% ogółu budynków podregionu. W momencie przyjęcia uregulowań prawnych umożliwiających korzystną ekonomicznie lokalizację instalacji mikroprosumenckich, również na działce obok zasilanych budynków, uwarunkowania budowlane przestały mieć znaczenie dominujące w procesie analizy miejsca lokalizacji instalacji fotowoltaicznej. 


\section{Efekty rozwoju mikroenergetyki w podregionie siedleckim}

Podstawowym wskaźnikiem merytorycznym określającym energetyczny efekt przyłączenia do sieci określonego wolumenu mocy elektrycznej ze źródeł odnawialnych jest udział energii wytworzonej przez przyłączone instalacje w ogólnym zużyciu energii na danym obszarze przyjętym do analiz. W odniesieniu do 2020 r. wskaźnik ten został ustalony $\mathrm{w}$ dokumencie [Krajowy plan działania w zakresie energii ze źródeł odnawialnych 2010] na poziomie $19,13 \%$ dla całego sektora krajowej elektroenergetyki odnawialnej, brak jest natomiast prognoz odnoszących się do poszczególnych województw oraz segmentu mikroenergetyki.

Według stanu na 31.12.2018 r., w podregionie siedleckim w sieci dystrybucyjnej niskiego napięcia (nN) pracowałołącznie 749 mikroinstalacji (ryc. 1) o sumarycznej mocy zainstalowanej 3,836 MW (ryc. 2). Są to instalacje wykonane w ramach programów inwestycyjnych samorządów gminnych, jak też przez inwestorów indywidualnych. Ich szacunkowa, realna roczna zdolność wytwórcza energii elektrycznej niskiego napięcia kształtuje się na poziomie około 3,4 GWh, co w odniesieniu do ogólnego zużycia energii elektrycznej nN w podregionie (dane od operatora sieci dystrybucyjnych za 2018 r.), wynoszącego $649 \mathrm{GWh}$, dało udział energii wytworzonej w segmencie mikro na poziomie jedynie około $0,52 \%$. Dla porównania, podane uśrednione na poziomie kraju (ale też regionu i odpowiednio podregionu) straty w sieci nN wynoszą (dane z 2016 r.) około 4,5\% przesyłanej tymi sieciami energii [VIII konferencja naukowo-techniczna, „Straty energii elektrycznej w sieciach elektroenergetycznych" 21-22 marca 2018 r., Wrocław]. W uproszczeniu stwierdzić można, że na obecnym etapie rozwoju segmentu mikroinstalacji, energia elektryczna wytworzona przez niego w podregionie siedleckim stanowi jedynie około $10 \%$ ogólnego wolumenu energii traconej w lokalnych sieciach dystrybucyjnych niskiego napięcia.

W zestawieniu (tabela 5) ilustrującym podział mikroinstalacji na zakresy mocy wynika, że pod względem liczebności dominują instalacje najmniejsze (poniżej $4 \mathrm{~kW}$ ), ale już w odniesieniu do mocy sumarycznej przodują instalacje z zakresu 4-6,9 kW. Istotną rolę w strukturze odgrywają też instalacje największe (21-50 kW) - 2,2\% łącznej liczby źródeł, co daje $16,4 \%$ sumy mocy wszystkich urządzeń mikrowytwórczych przyłączonych $\mathrm{w}$ podregionie do sieci dystrybucyjnych $\mathrm{nN}$. 


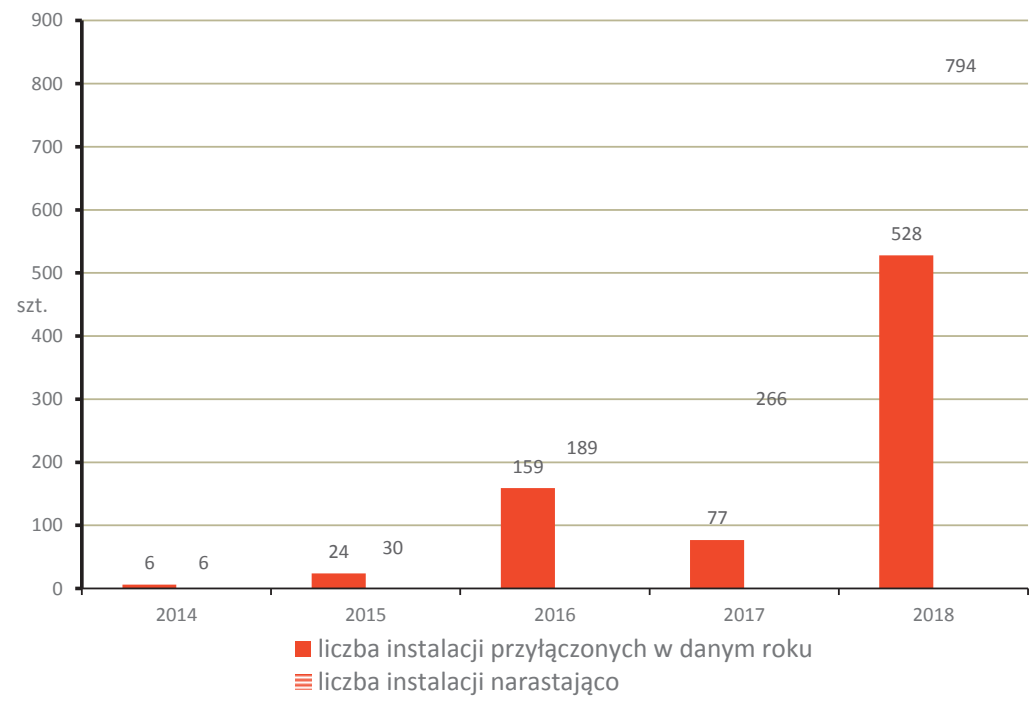

Ryc. 1. Mikroinstalacje OZE przyłączone w podregionie siedleckim do sieci dystrybucyjnych niskiego napięcia 0,4 kV w latach 2014-2018

Źródło: opracowanie własne MBPR na podstawie danych uzyskanych w badaniu ankietowym gmin i od PGE Dystrybucja S.A.

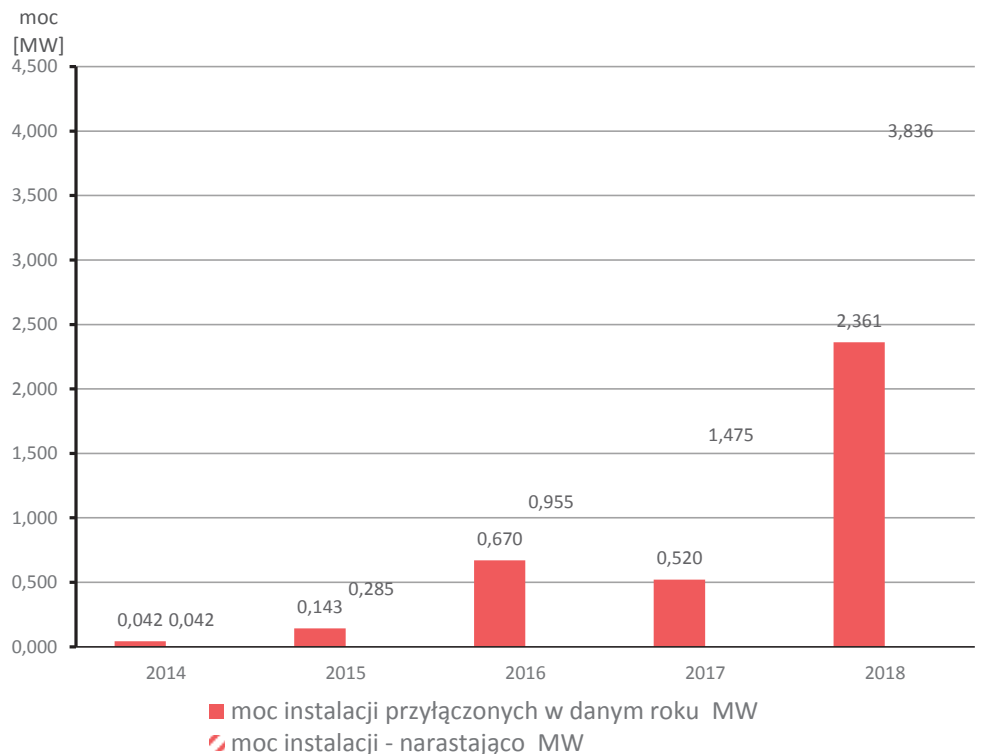

Ryc. 2. Moc [MW] mikroinstalacji OZE przyłączonych w podregionie siedleckim do sieci dystrybucyjnych niskiego napięcia 0,4 kV w latach 2014-2018

Źródło: opracowanie własne MBPR na podstawie danych uzyskanych w badaniu ankietowym gmin i od PGE Dystrybucja S.A. 


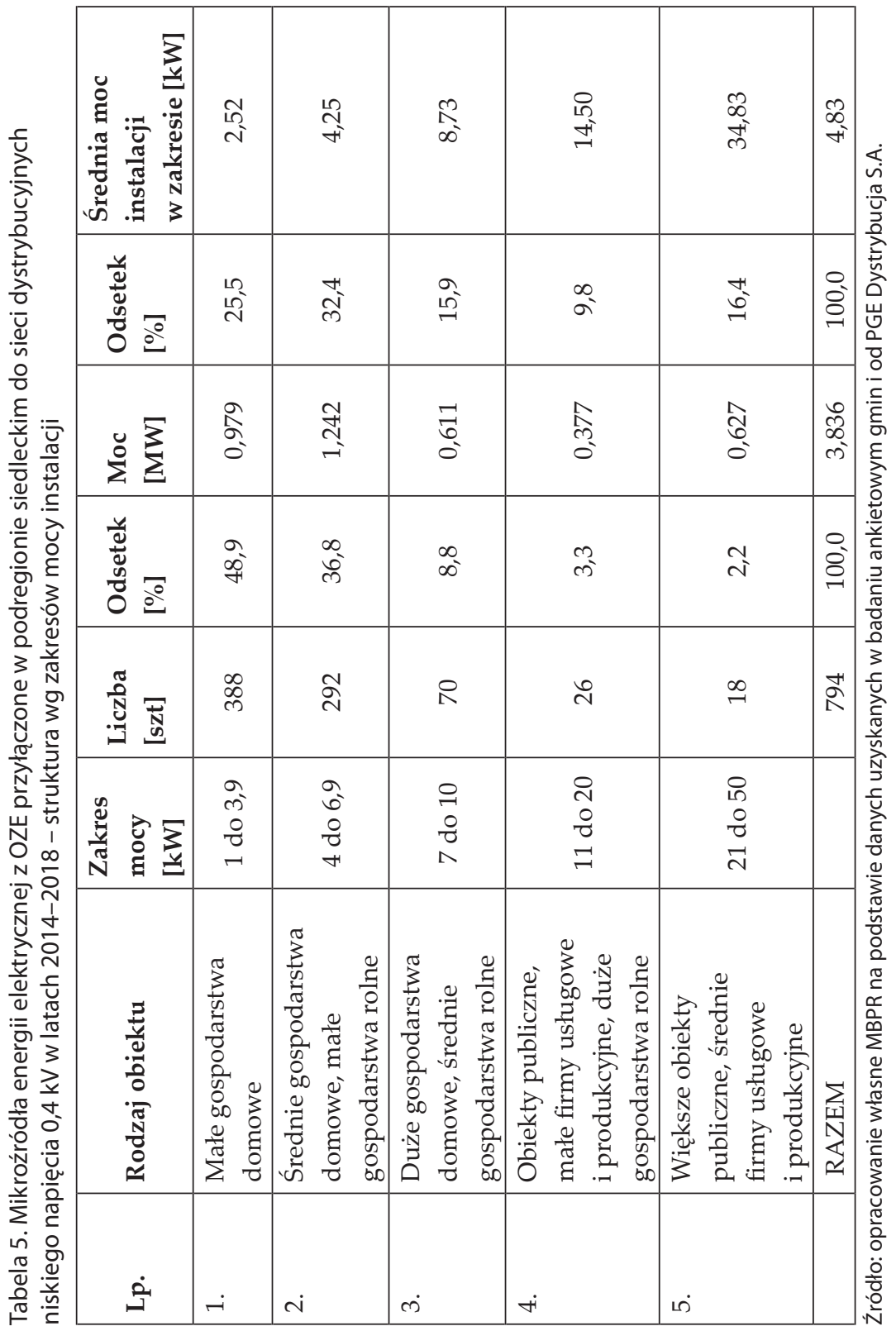


Stopień rozwoju segmentu mikroinstalacji jest w ujęciu przestrzennym mocno zróżnicowany (ryc. 3). Jedynie w 11 gminach (21,2\% jednostek w podregionie) osiągnął poziom, który można określić jako zauważalny, bowiem w tych gminach udział produkcji energii elektrycznej wyprodukowanej przez mikroinstalacje $\mathrm{nN}$ w ogólnej konsumpcji energii elektrycznej nN (wyprodukowanej z surowców kopalnych i OZE) kształtuje się na poziomie powyżej 1\% ogólnej konsumpcji energii $\mathrm{nN}$. W dalszych 8 gminach $(15,4 \%)$ omawiany wskaźnik zawiera się w przedziale 0,5-0,9\%, czyli około i nieco powyżej średniego dla podregionu. Najlepsze efekty uzyskały gminy: Stoczek (6,2\%), Korczew (2,6\%), Łochów $(2,3 \%)$, Bielany (1,9\%). W odniesieniu do mocy zainstalowanej jest to odpowiednio: $666 \mathrm{~kW}$, $370 \mathrm{~kW}, 97 \mathrm{~kW}, 117 \mathrm{~kW}$.

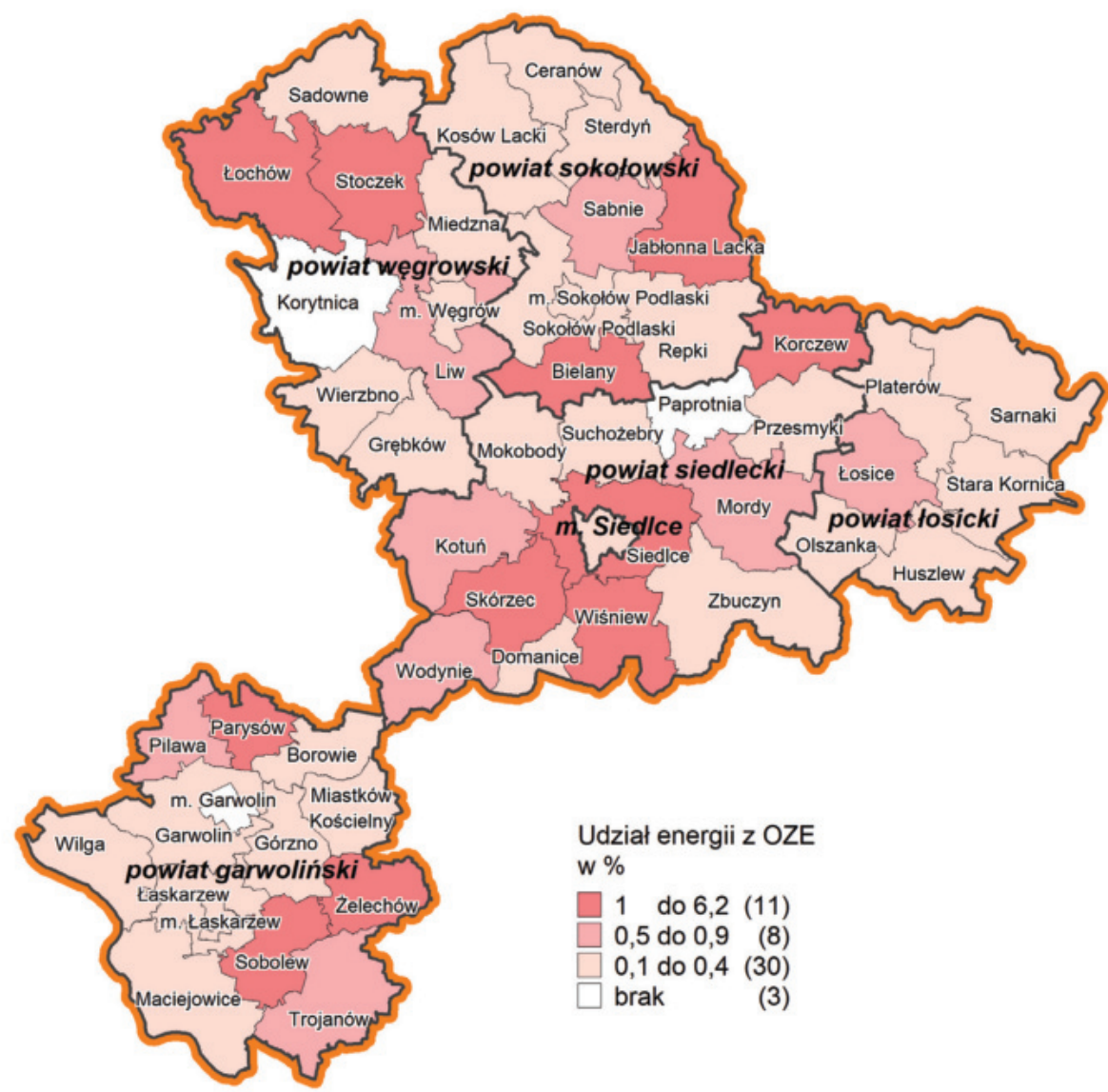

Ryc. 3. Udział wyprodukowanej w gminach podregionu siedleckiego energii elektrycznej z mikroźródeł OZE w ogólnym zużyciu w nich energii elektrycznej niskiego napięcia - stan na 31.12.2018 r.

Źródło: opracowanie własne MBPR na podstawie danych uzyskanych w badaniu ankietowymgmin i od PGE Dystrybucja S.A. 
Następnym, istotnym wskaźnikiem syntetycznym, ilustrującym stopień rozwoju mikroenergetyki w gminie jest tzw. wskaźnik systemowy, określający udział łącznej mocy mikroźródeł przyłączonych do sieci $\mathrm{nN}$ w łącznej mocy transformatorów SN/nN zainstalowanych w gminie. Ma on głównie charakter uogólnionego, technicznego miernika zdolności przyłączeniowej lokalnego ( $w$ tym wypadku zlokalizowanego w gminie) systemu sieci dystrybucyjnych. Bardziej istotne i stosowane $\mathrm{w}$ praktyce jest monitorowanie tej zdolności na poziomie pojedynczych stacji trafo SN/nN. Taką ewidencję uzupełnioną o parametry linii nN (rodzaj i przekrój przewodów, długość obwodów, liczba odbiorców, moce przyłączeniowe odbiorów, szczytowe obciążenia) prowadzą przedsiębiorstwa dystrybucyjne przy analizie wniosków o przyłączenie instalacji wytwórczych.

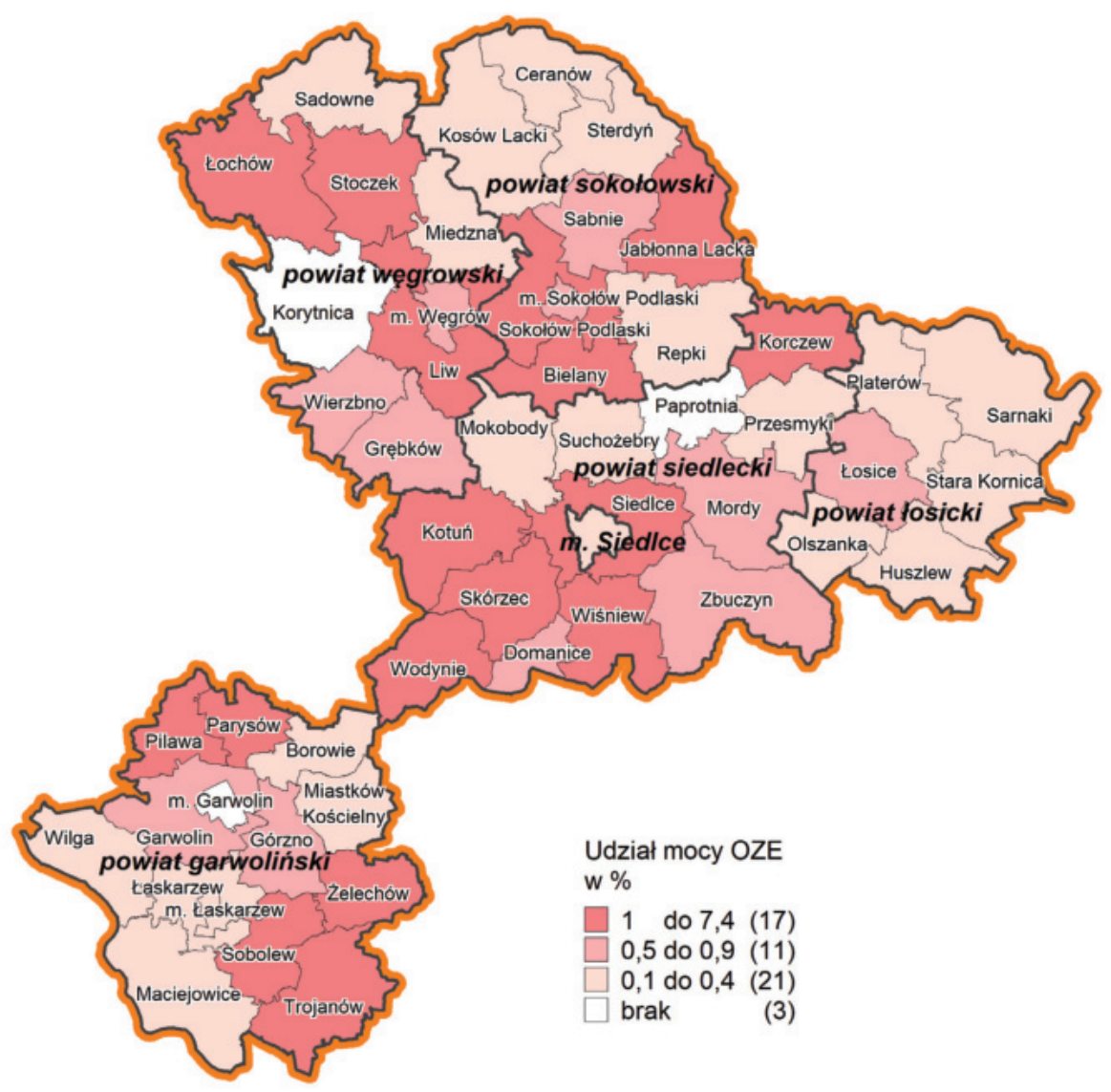

Ryc. 4. Udział mocy mikroźródeł OZE w mocy zainstalowanej w stacjach trafo 15/0,4 kV w gminach podregionu siedleckiego - stan na 31.12.2018 r.

Źródło: opracowanie własne MBPR na podstawie danych uzyskanych w badaniu ankietowym gmin i od PGE Dystrybucja S.A. 
W podregionie siedleckim (ryc. 4) omawiany wskaźnik kształtował się na średnim poziomie $0,8 \%$. Najwyższe wartości notuje się dla gmin: Stoczek 7,4\%, Łochów 3,5\% oraz Korczew, Bielany i Żelechów - po 2,7\%.

Kolejny, uzupełniający wskaźnik syntetyczny, ilustrujący stopień rozwoju segmentu mikroenergetyki w gminach podaje odsetek odbiorców energii elektrycznej posiadających mikroźródła tej energii wytwarzanej z OZE. Średnia wartość dla podregionu siedleckiego wynosi $0,4 \%$. Również i w tej kategorii przodują gminy wyróżniające się $\mathrm{w}$ dwóch poprzednich listach rankingowych: Stoczek 5,6\%, Łochów 2,5\%, Bielany 1,7\%, Korczew 1,4\%.

$\mathrm{W}$ podsumowaniu analizy stopnia rozwoju segmentu mikreoenergetyki stwierdzić należy, iż pomimo blisko sześcioletniego już okresu funkcjonowania prawnego, organizacyjnego i ekonomicznego, skierowanego systemu wsparcia, uzyskane efekty rzeczowe są znacznie mniejsze od prognozowanych. Przedstawiona w tabeli 1. i oparta na pochodzącej z 2015 r. prognozie rozwoju mikroelektroenergetyki prosumenckiej [Cieszkowski, Girczuk, Polak 2015] łączna moc instalacji przewidywana dla podregionu siedleckiego na $2018 \mathrm{r}$. wynosiła 32,1 MW, podczas gdy rzeczywista osiągnęła poziom jedynie 3,8 MW, czyli 13,4\% wielkości prognozowanej. W odniesieniu do zdolności wytwórczej jest to około 35000 MWh prognozowanej i około 3400 MWh osiągniętej. Przy rzeczywistym, zanotowanym w 2018 - rocznym zużyciu energii elektrycznej niskiego napięcia wynoszącym $649000 \mathrm{MWh}$ (649 GWh), prognozowany udział energii wytworzonej $\mathrm{w}$ przyłączonych do sieci mikroinstalacjach miał wynosić około $5,4 \%$, podczas gdy osiągnięty był 10-krotnie mniejszy (0,52\%). Zgodnie z obecnym (lipiec 2019 r.) stanem wiedzy, przyjęte w 2015 r. założenia prognostyczne były jednak przesadnie optymistyczne $\mathrm{w}$ odniesieniu do rzeczywistej polityki energetycznej państwa, realnych systemów wsparcia, które nie spełniały oczekiwań społecznych i rynkowych reguł wytwarzania i użytkowania energii. W praktyce rozwijała się jedynie mikroelektronergetyka fotowoltaiczna, bowiem na 794 instalacje jedynie po 1 wykonano $\mathrm{w}$ technologii wykorzystującej energię wody i wiatru. $W$ ramach inwestycji prowadzonych przez samorządy gminne zrealizowano 458 mikroinstalacji elektroenergetycznych, co stanowi 57,7\% wszystkich funkcjonujących w podregionie, a w odniesieniu do łącznej mocy instalacji jest to 43,5\%.

W dziedzinie mikroprodukcji ciepła, działania inwestycyjne prowadziło jedynie 20 (38,5\%) gmin (ryc. 5), przy czym jedynie 7 gmin zrealizowało programy inwestycyjne o stosunkowo szerokim zakresie. Objęto nimi montaż kolektorów słonecznych do podgrzewania ciepłej wody użytkowej lub pomp ciepła do ogrzewania pomieszczeń i podgrzewania wody. Inwestycje wykonywano na użytek gminnych obiektów publicznych oraz budynków mieszkalnych i gospodarstw rolnych mieszkańców gminy. W przypadku mikroenergetyki cieplnej brak jest danych o inwestycjach realizowanych przez indywidualnych mikroproducentów poza programami prowadzonymi przez samorządy gminne, bowiem nie są one ewidencjonowane $\mathrm{w}$ urzędach gminnych i wydziałach budownictwa starostw powiatowych. 


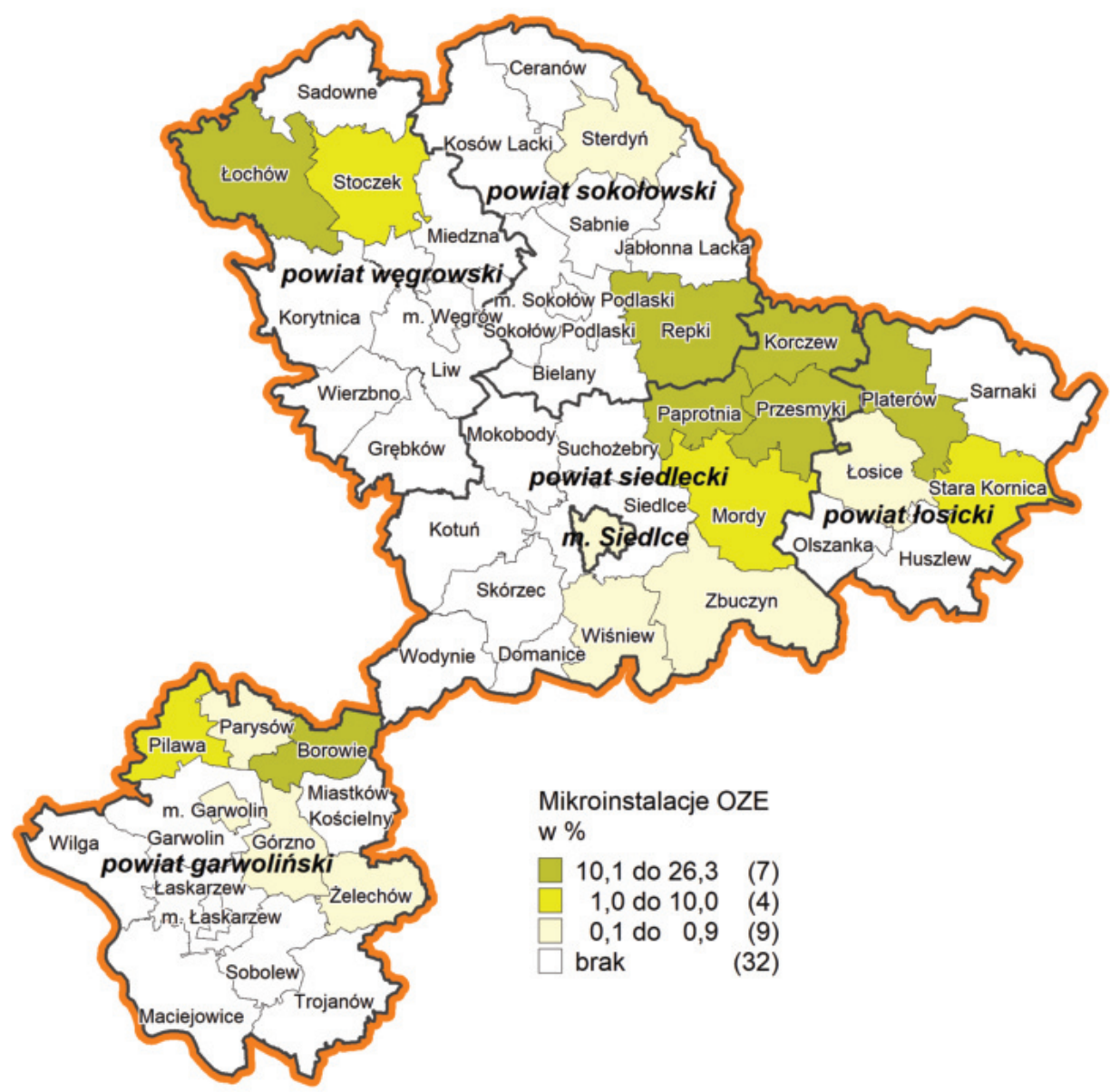

Ryc. 5. Udział mikroinstalacji OZE w ogólnej liczbie indywidualnych źródeł ciepła w gminach podregionu siedleckiego -stan na 31.12.2018 r.

Źródło: opracowanie własne MBPR na podstawie danych uzyskanych w badaniu ankietowym gmin

W odniesieniu do możliwych do pozyskania w ramach niniejszego zakresu badań danych, jedynym wskaźnikiem ilustrującym stopień rozwoju mikroenergetyki cieplnej wykorzystującej OZE jest procentowy udział tych instalacji w ogólnej liczbie wszystkich indywidualnych źródeł ciepła. Z tej kategorii wyłączone są systemy zbiorowego zaopatrzenia w ciepło.

Najwyższe wskaźniki w rozwoju mikroenergetyki cieplnej osiągnęły gminy: Repki 26,3\%, Platerów 26,2\%, Przesmyki 25,5\%, Borowie 23,2 \%, Paprotnia 22,9\%, Korczew 16,5\% i Łochów 14,5\%, a więc na 100 indywidualnych źródeł ciepła, od około 26 do około 15 korzysta z ekologicznego wspomagania w przygotowaniu ciepłej wody użytkowej lub ogrzewania pomieszczeń. Dalszych 13 gmin zrealizowało niewielkie, pilotażowe programy inwestycyjne, natomiast aż 32 gminy (61,5\%) nie wykonało żadnych. 


\section{Aktywność inwestycyjna gmin podregionu siedleckiego}

W ramach prac badawczych dotyczących aktywności poszczególnych gmin w realizacji programów inwestycyjnych wykorzystujących środki unijne, sporządzono dla badanego obszaru wykresy ogólne dotyczące liczebności (ryc. 6) oraz mocy (ryc. 7) mikroinstalacji OZE w rozbiciu na instalacje wykonane i planowane w odniesieniu do miejsca lokalizacji (obiekty publiczne zarządzane przez gminy i budynki mieszkańców gmin) oraz stosowanych technologii (instalacje fotowoltaiczne, kolektory słoneczne, pompy ciepła). Z wykresów wynika wyraźna dominacja zrealizowanych i planowanych działań inwestycyjnych w obszarze wytwarzania ciepła do podgrzewania wody użytkowej w instalacjach zbudowanych na bazie kolektorów słonecznych. Pompy ciepła służące głównie do ogrzewania pomieszczeń w większych obiektach publicznych i produkcyjnych sa, jak widać, znacznie mniej wykorzystywane ze względu na cenę instalacji. Jako bardzo perspektywiczne uznać należy elektroenergetyczne mikroinstalacje fotowoltaiczne, tu bowiem występuje największy stosunek instalacji planowanych w odniesieniu do zrealizowanych (4,5 dla liczby instalacji i 6,6 dla mocy). Zdecydowana większość inwestycji zrealizowana została przez gminy z wykorzystaniem środków unijnych $\mathrm{w}$ ramach wdrażanych przez jednostki podległe samorządowi województwa mazowieckiego programom operacyjnym, w tym RPOWM 2007-2013 i RPOWM 2014-2020.

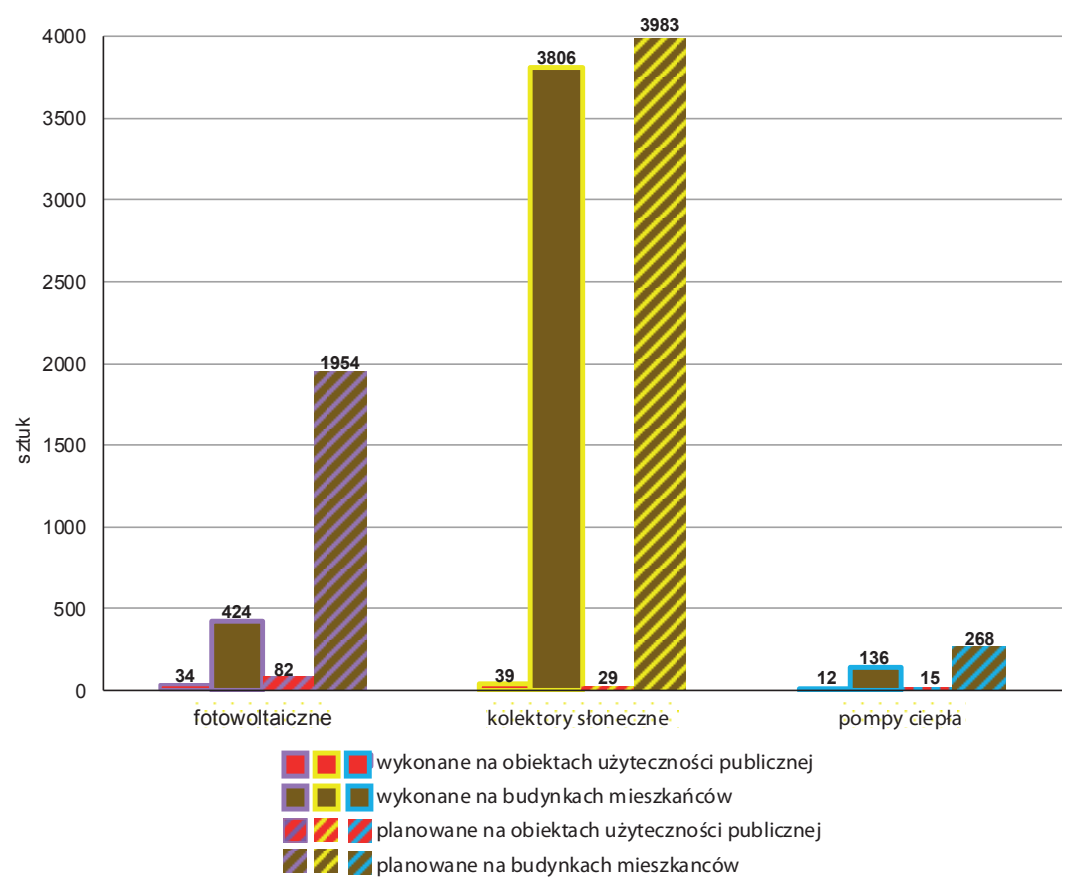

Ryc. 6. Mikroinstalacje OZE wykonane i planowane w podregionie siedleckim w ramach gminnych programów inwestycyjnych - stan na 31.12.2018 r.

Źródło: opracowanie własne MBPR na podstawie danych uzyskanych w badaniu ankietowym gmin 


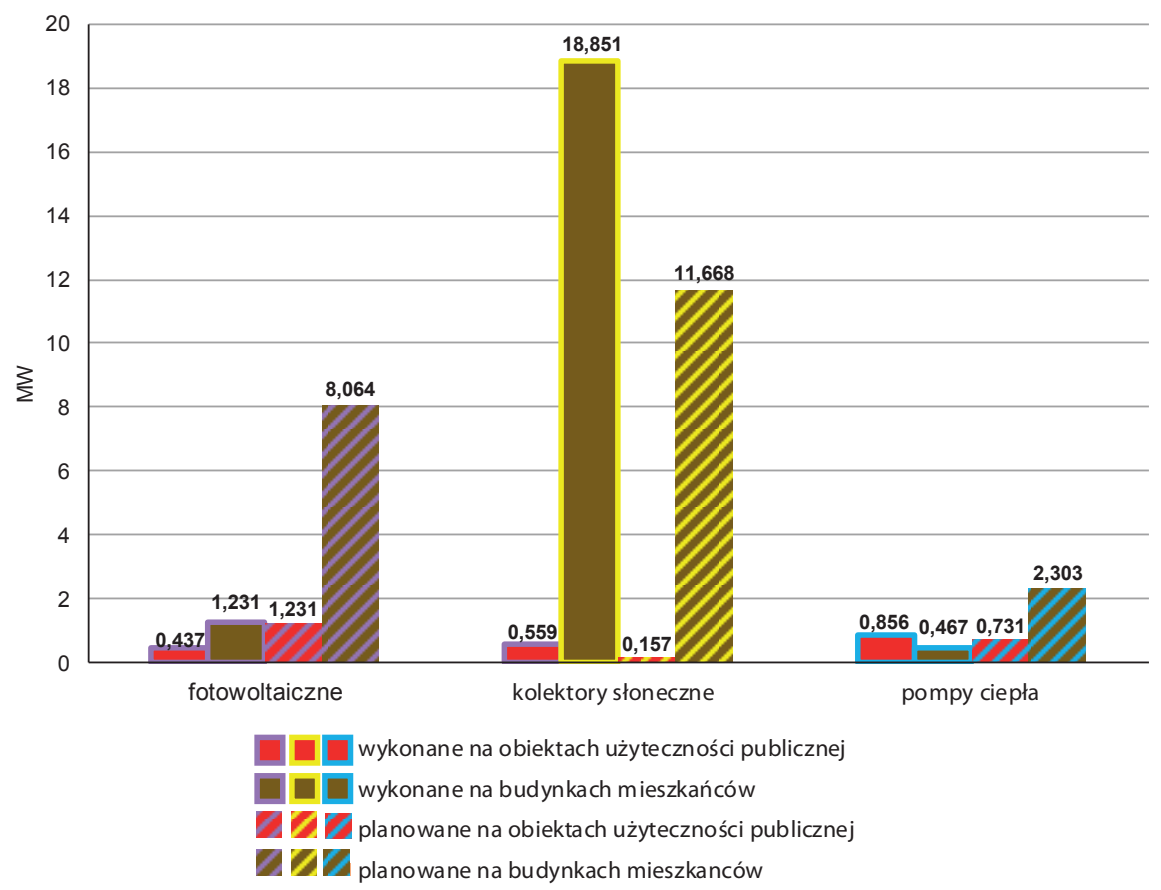

Ryc. 7. Moc mikroinstalacji OZE wykonanych i planowanych w podregionie siedleckim w ramach gminnych programów inwestycyjnych - stan na 31.12.2018 r.

Źródło: opracowanie własne MBPR na podstawie danych uzyskanych w badaniu ankietowym gmin

Programy inwestycyjne w zakresie rozwoju mikroelektroenergetyki prosumenckiej (ryc. 8) zrealizowało jedynie 14 (26,9\%) gmin, przy czym jedynie 4 (7,7\%) osiągnęło efekty rzeczowe, które określić można jako zauważalne, czyli na 100 odbiorców energii elektrycznej niskiego napięcia, od 1 do około 10 odbiorców stało się prosumentami energii elektrycznej. Realizację programów rozwojowych w tym zakresie deklaruje 27 (51,9\%) gmin, w tym 18 (34,6\%) zamierza osiągnać efekty docelowe w wymiarze od 1 do około 14 instalacji fotowoltaicznych przypadających na 100 odbiorców energii elektrycznej. Wśród gmin (Stoczek, Łochów, Sobolew, Korczew) przodujących w klasyfikacji w grupie inwestycji zrealizowanych, jedynie Korczew planuje realizację kolejnego programu rozwoju instalacji fotowoltaicznych, natomiast na uwagę zasługują również 2 inne gminy, a mianowicie Suchożebry i Platerów, które po pomyślnym zakończeniu inwestycji będą $\mathrm{w}$ podregionie siedleckim liderami, osiągając odpowiednio wskaźniki na poziomie 14,4 i 11,5 instalacji prosumenckich na 100 konsumentów energii elektrycznej. Niepokojący jest fakt, że aż 18 gmin (34,6\%) nie zrealizowało i nie planuje (stan z lipca 2019 r.) realizacji programów rozwoju mikroelektroenergetyki prosumenckiej. Dotyczy to szczególnie powiatów garwolińskiego i łosickiego, w których brak działań i planów inwestycyjnych wykazuje odpowiednio 57,1\% i 50\% gmin. 


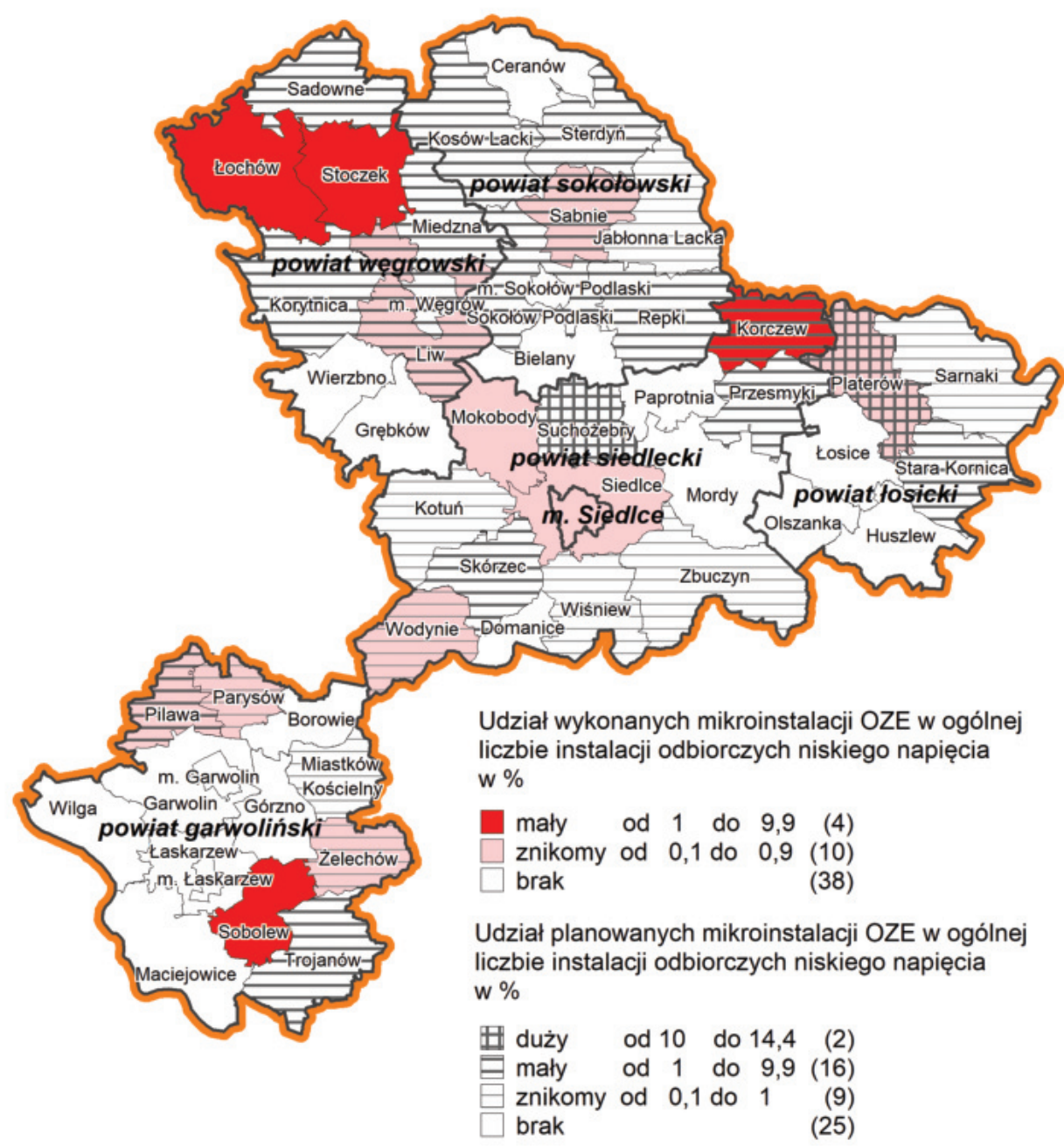

Ryc. 8. Aktywność inwestycyjna gmin podregionu siedleckiego w rozwoju lokalnej mikroelektroenergetyki odnawialnej - stan na 31.12.2018 r.

Źródło: opracowanie własne MBPR na podstawie danych uzyskanych w badaniu ankietowym gmin

W działaniach na rzecz rozwoju mikroinstalacji służących produkcji ciepła (ryc. 9) aktywnymi było 20 (38,4\%) gmin, z których 11 (21,2\%) zrealizowało inwestycje, w efekcie których, od 1 do 26 indywidualnych, tradycyjnych źródeł ciepła w obiektach gminnych lub budynkach mieszkańców otrzymało wsparcie w postaci kolektorów słonecznych lub pomp ciepła. Plany inwestycyjne o zauważalnym zakresie ma $20(38,4 \%)$ gmin, dalsze 5 (9,6\%) planuje minimalny zakres prac, natomiast całkowicie biernymi okazuje się 17 (32,7\%) gmin, które nie wykonały i nie planują rozwoju mikroenergetyki cieplnej. Do grona liderów, 
którzy osiągnęli najlepsze wyniki i dalej prowadzą aktywną politykę inwestycyjną należą gminy: Repki, Przesmyki, Korczew, Platerów. Znajdujące się w czołówce Stoczek i Paprotnia nie podjęły dalszych działań, natomiast Sokołów Podlaski (gmina wiejska), Stara Kornica, Olszanka i Suchożebry to gminy o największym zakresie inwestycji planowanych.

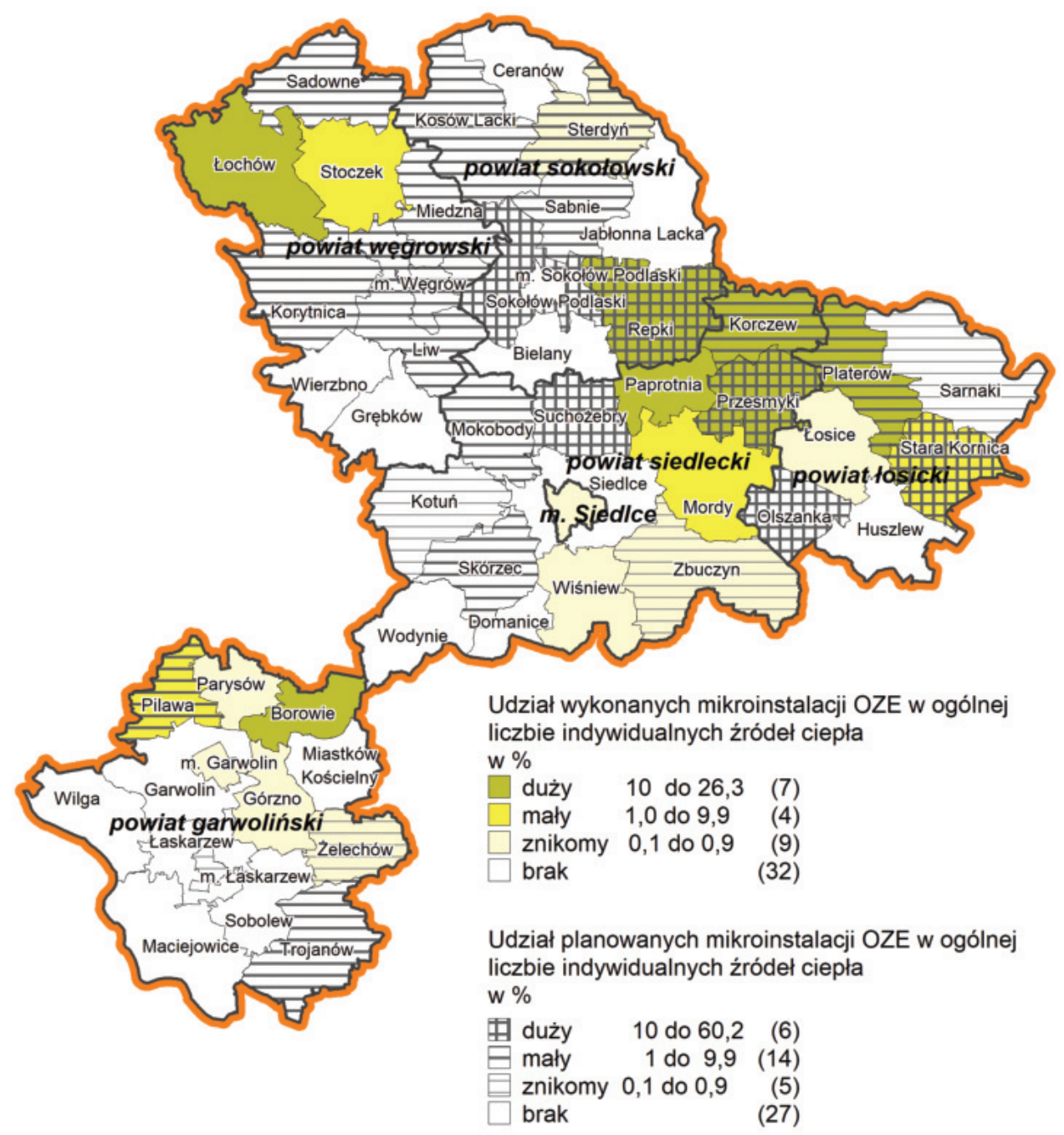

Ryc. 9. Aktywność inwestycyjna gmin podregionu siedleckiego w rozwoju odnawialnej mikroenergetyki cieplnej - stan na 31.12.2018 r.

Źródło: opracowanie własne MBPR na podstawie danych uzyskanych w badaniu ankietowym gmin 
W podsumowaniu analizy aktywności inwestycyjnej gmin podregionu siedleckiego w obszarze rozwoju mikroenergetyki, stwierdzić należy, że pomimo 12-letniego już okresu dostępności funduszy unijnych wspomagających rozwój lokalnego wykorzystania OZE w działaniach na rzecz poprawy efektywności energetycznej, stanu środowiska oraz wzrostu bezpieczeństwa energetycznego, znaczna liczba gmin jest $\mathrm{w}$ tej dziedzinie całkowicie nieaktywna - 18 gmin $(34,6 \%)$ w mikroelektronergetyce i $17(32,7 \%) \mathrm{w}$ mikroenergetyce cieplnej.

W badaniu ankietowym, jako przyczynę takiej postawy podawano brak środków finansowych na wkład własny gminy, małą pulę dostępnych środków zewnętrznych oraz brak zainteresowania mieszkańców. Jednak zdaniem autora niniejszego opracowania, w grę wchodzą również jeszcze dodatkowe przyczyny subiektywne. Ich identyfikacja wymaga jednak odrębnych, specjalistycznych badań ukierunkowanych na indywidualne, skierowane do poszczególnych gmin programy doradcze.

W zakresie dostępnych danych GUS dotyczących rocznych dochodów gmin podregionu przypadających na mieszkańca gminy, zbadano (ryc. 10) wpływ wysokości tych dochodów (uśrednionych dla lat 2014-2017) na aktywność samorządów w obszarze rozwoju mikroenergetyki cieplnej, jako dominującej pod względem ilości i sumarycznej mocy wykonanych instalacji. Rozpiętość wartości jest znaczna - od minimalnej na poziomie 3135 zł (Wilga) poprzez 3642 zł (średnia subregionu) aż po maksymalną w wymiarze 5482 zł (miasto Siedlce). Okazało się, że wśród 4 gmin o najwyższych dochodach, 2 jednostki zrealizowały programy inwestycyjne, natomiast wśród 19 gmin o dochodach najniższych, aktywnymi inwestycyjnie było jedynie 6 (31,6\%), które w zdecydowanej większości(z wyjątkiem 1 gminy) zrealizowały programy o niskich efektach rzeczowych. Wśród 29 gmin o dochodach średnich, 11 (37,9\%) było aktywnych. Wśród 7 gmin o najwyższych efektach inwestycyjnych - 1 należy do grupy o dochodach wysokich, 5 średnich i 1 najniższych. Jak wynika z powyższych analiz, wysokość dochodów gmin wywiera pewien wpływ na ich politykę klimatyczno-energetyczną, aczkolwiek nie można uznać tego wpływu za przesądzający.

Wśród pozostałych (innych niż finansowe) uwarunkowań, które możliwe były do zdiagnozowania $\mathrm{w}$ toku badania ankietowego gmin podregionu siedleckiego, jako bardzo istotne uznano:

- aktywność planistyczną gmin w obszarze energetyki i środowiska, polegającą na sporządzeniu podstawowych dokumentów, czyli: Założeń do planu zaopatrzenia w ciepło, energię elektryczną i paliwa gazowe oraz Planu gospodarki niskoemisyjnej,

- działalność edukacyjną w obszarze polityki klimatyczno-energetycznej,

- $\quad$ stopień zainteresowania mieszkańców gmin rozwojem nowoczesnej mikroenergetyki lokalnej opartej o wykorzystanie OZE. 


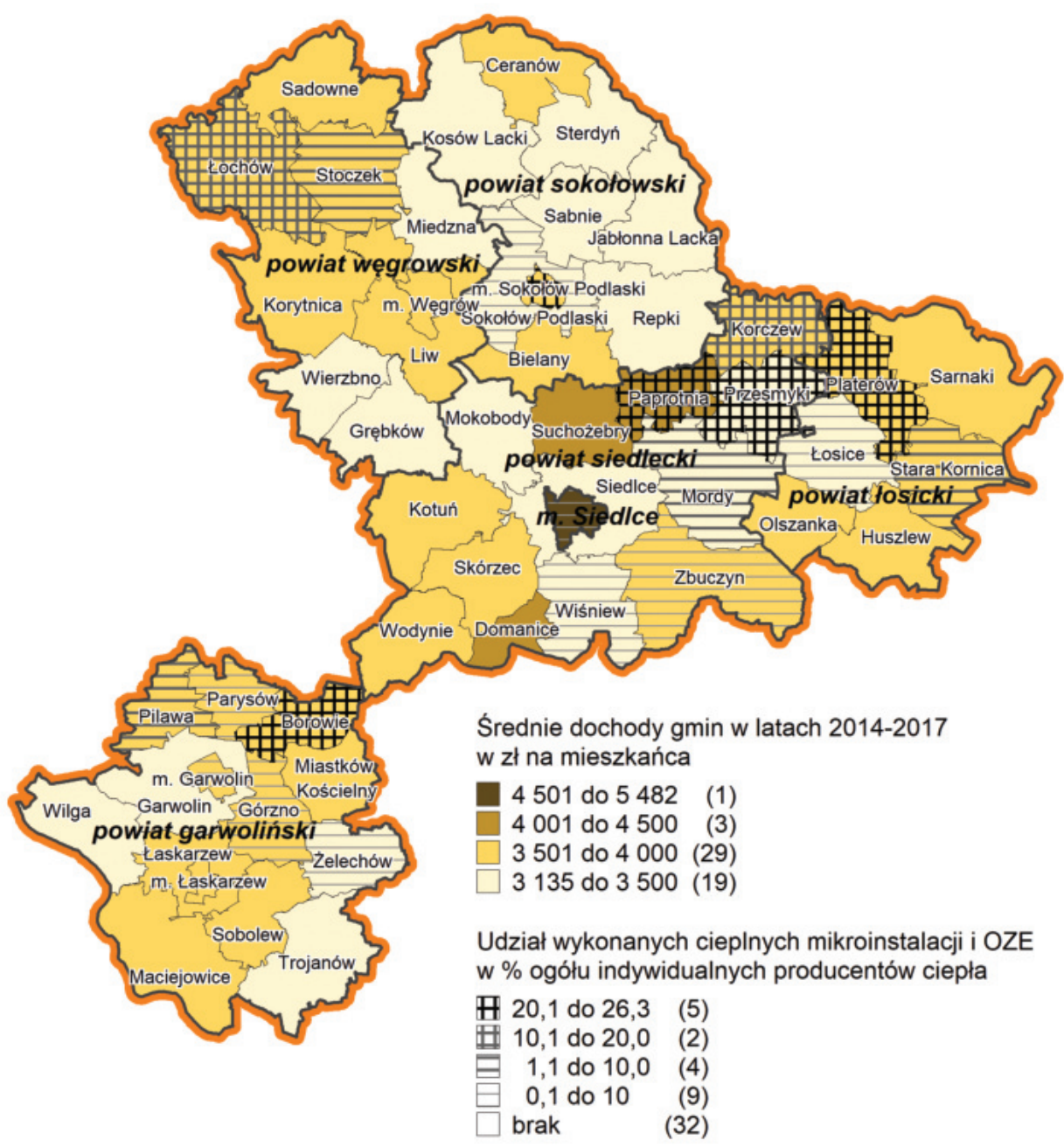

Ryc. 10. Wpływ wysokości dochodów gmin podregionu siedleckiego na ich aktywność inwestycyjną w obszarze mikroenergetyki cieplnej - mikroinstalacje OZE wg stanu na 31.12.2018 r.

Źródło: opracowanie własne MBPR na podstawie danych uzyskanych w badaniu ankietowym gmin oraz danych GUS 


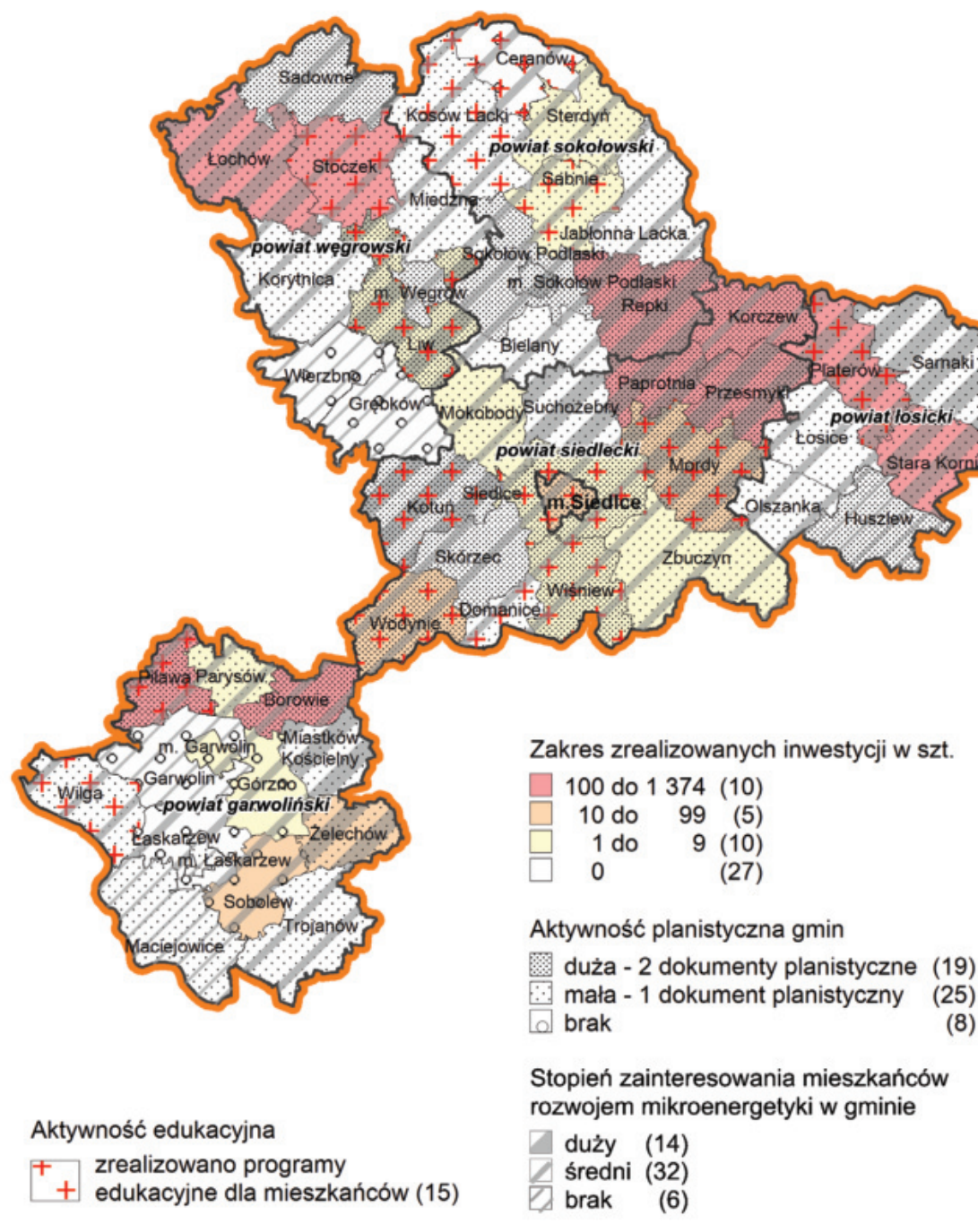

Ryc. 11. Wpływ aktywności planistycznej i edukacyjnej władz gminnych w podregionie siedleckim oraz stopnia zainteresowania mieszkańców gmin na rozwój energetyki prosumenckiej Źródło: opracowanie własne MBPR na podstawie danych uzyskanych w badaniu ankietowym gmin

Wśród 19 gmin o największej aktywności planistycznej (2 opracowane dokumenty pla-nistyczne), 12 (63,2\%) gmin zrealizowało inwestycje w obszarze mikroenergetyki lokalnej (łączne dla produkcji energii elektrycznej i ciepła), natomiast wśród 25 jednostek mających na koncie 1 opracowanie, było to 12 (48\%) gmin. Programy inwestycyjne zrealizowały także 3 gminy $(37,5 \%)$ w grupie 8 nieaktywnych planistycznie. Wśród 14 gmin, które w ankietach wskazały na duże zainteresowanie mieszkańców rozwojem 
mikroenergetyki lokalnej - 8 (57,1\%) wykonało inwestycje mikroenergetyczne. W grupie 32 gmin o zainteresowaniu średnim było to 13 (40,6\%). Spośród 15 gmin, które zorganizowały dla swoich mieszkańców programy informacyjne, 7 (46,7\%) zdołało również osiągnąć wymierne efekty inwestycyjne. W podsumowaniu stwierdzić należy, że stosunkowo wysoki, wynoszący 84,6\% wskaźnik aktywności planistycznej gmin, jak również podobny odsetek $(85,2 \%)$ jednostek o dużym i średnim stopniu zainteresowania mieszkańców problematyką energetyki lokalnej, nie przełożył się $\mathrm{w}$ podobnym stosunku na uzyskane efekty inwestycyjne, bowiem tylko 48,2\% gmin wg stanu na lipiec 2019 r. zdołało takie efekty osiągnąć. W trakcie realizacji lub planowania inwestycji jest 30,8\% samorządów, które nie sfinalizowały dotychczas żadnej inwestycji, a więc zaangażowanych w procesie rozwoju mikroenergetyki lokalnej jest łącznie 79\% gmin.

\section{Prognoza rozwoju segmentu mikroelektroenergetyki - 2020 r. Podregion siedlecki}

W prognozie ujęto około 9,3 MW mocy planowanej do przyłączenia do sieci elektroenergetycznej $\mathrm{w}$ ramach realizacji gminnych programów inwestycyjnych oraz szacunkowo około 13,2 MW mocy prognozowanej do realizacji przez inwestorów indywidualnych z wykorzystaniem wsparcia rządowego, w tym pochodzącego z programów Mój prąd i AgroEnergia. Szacuje się, że łączna moc mikroinstalacji pracujących w sieciach dystrybucyjnych niskiego napięcia osiągnie w podregionie siedleckim wartość około 23,3 MW o potencjale wytwórczym rzędu 23,7 GWh. Prognozowane na koniec 2020 r. zapotrzebowanie podregionu na energię elektryczną niskiego napięcia wyniesie około $662 \mathrm{GWh}$.

Przy uwzględnieniu przewidywanego wpływu wprowadzonych w kraju istotnych, korzystnych zmian uwarunkowań prawnych i organizacyjno-ekonomicznych, przy założeniu pełnej realizacji gminnych planów inwestycyjnych, szacuje się, że na koniec 2020 r. podregion siedlecki może osiągnąć około 3,6\% udziału pochodzącej z mikroźródeł energii elektrycznej w ogólnej konsumpcji energii niskiego napięcia. W porównaniu z osiągniętym na 31.12.2018 r. wskaźnikiem o wartości 0,52\%, stanowić to będzie wzrost aż około 7-krotny, gdyż skala rozszerzonego w 2019 r. wsparcia rządowego i duży zakres inwestycji realizowanych $\mathrm{w}$ ramach programów gminnych, wykorzystujących środki unijne (głównie RPOWM 2014-2020), daje mocne podstawy do powyższych szacunków. 


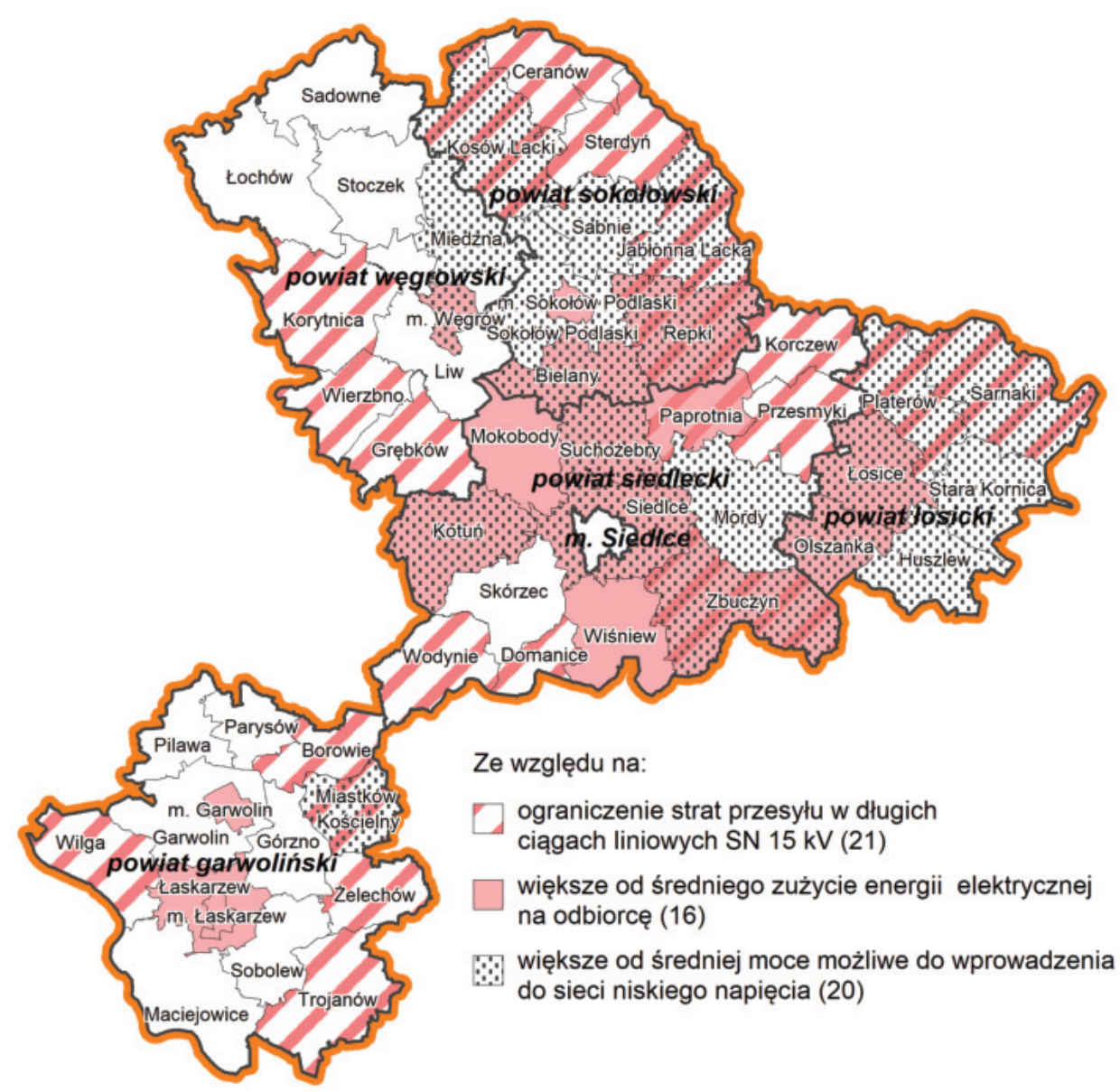

Ryc. 12. Gminy podregionu siedleckiego preferowane do szczególnej koordynacji i wspomagania rozwoju lokalnego wytwarzania energii elektrycznej w mikroinstalacjach prosumenckich

Źródło: opracowanie własne MBPR na podstawie badań własnych i danych uzyskanych od PGE Dystrybucja S.A.

Jak już wcześniej wspomniano, proces rozwoju mikroelektroenergetyki prosumenckiej winien przebiegać $\mathrm{w}$ sposób kontrolowany, dotyczy to zwłaszcza dużych programów gminnych, w efekcie których przyłączane do sieci będą znaczne ilości mikroźródeł wytwórczych czy teżźródła o większych mocach. Współpraca inwestora z przedsiębiorstwem dystrybucyjnym pozwoli na harmonijne wykorzystanie istniejącej infrastruktury sieciowej, właściwe zaplanowanie jej modernizacji i rozbudowy, a przez to osiągnięcie właściwych efektów energetycznych i ekologicznych, przy minimalizacji nakładów finansowych. 
Indywidualne problemy i cechy charakterystyczne systemów sieciowych zasilających poszczególne gminy, zilustrowano (ryc. 12), akcentując problemy wymagające współpracy i wzajemnego wsparcia stron uczestniczących w procesie rozwoju mikroenergetyki OZE. Niezwykle istotne znaczenie ma odpowiedni do potrzeb i profilu energetycznego odbiorcy dobór mocy planowanej instalacji wytwórczej, a także taka organizacja użytkowania energii, która pozwoli na maksymalizację wykorzystania wyprodukowanej energii na potrzeby własne. Do czasu skonstruowania ekonomicznie opłacalnych magazynów energii ograniczających przesyłanie do sieci jej nadwyżek wytworzonych w mikroinstalacjach prosumenckich, stopień oddziaływania na rozległe, szczególnie wiejskie sieci dystrybucyjne dużej liczby rozproszonych mikroźródeł energii będzie główną barierą techniczną rozwoju tego segmentu energetyki odnawialnej.

\section{Efekty rozwoju mikroelektroenergetyki w województwie mazowieckim}

W odniesieniu do innych niż siedlecki podregionów województwa mazowieckiego dysponowano jedynie uzyskiwanymi corocznie (w latach 2012-2018) od przedsiębiorstw dystrybucyjnych danymi (bez informacji o inwestorach) o liczebności i mocy mikroźródeł energii elektrycznej pracujących w lokalnych sieciach dystrybucyjnych. Na ich podstawie opracowano ilustrację (ryc. 13) rozwoju segmentu w poszczególnych podregionach oraz ogólne zestawienie tabelaryczne (tabela 6) liczby i mocy mikroinstalacji. Widoczny przyrost następował w latach 2016-2018 w wyniku wprowadzenia krajowych uregulowań prawnych i ekonomicznych, przeznaczonych dla wspomagania rozwoju rynku prosumenckiego. Według stanu na 31.12.2018 r. w województwie, w sieciach niskiego napięcia, funkcjonowało 6212 mikroinstalacji o łącznej mocy ponad 37,5 MW. Największe wolumeny mocy zainstalowano w podregionach: miasto Warszawa oraz warszawski zachodni i radomski. Znajomość łącznej mocy instalacji zainstalowanych w gminach i podregionach pozwoliła na szacunkowe wyliczenie rocznych wolumenów energii elektrycznej wytworzonych na ich obszarach. 


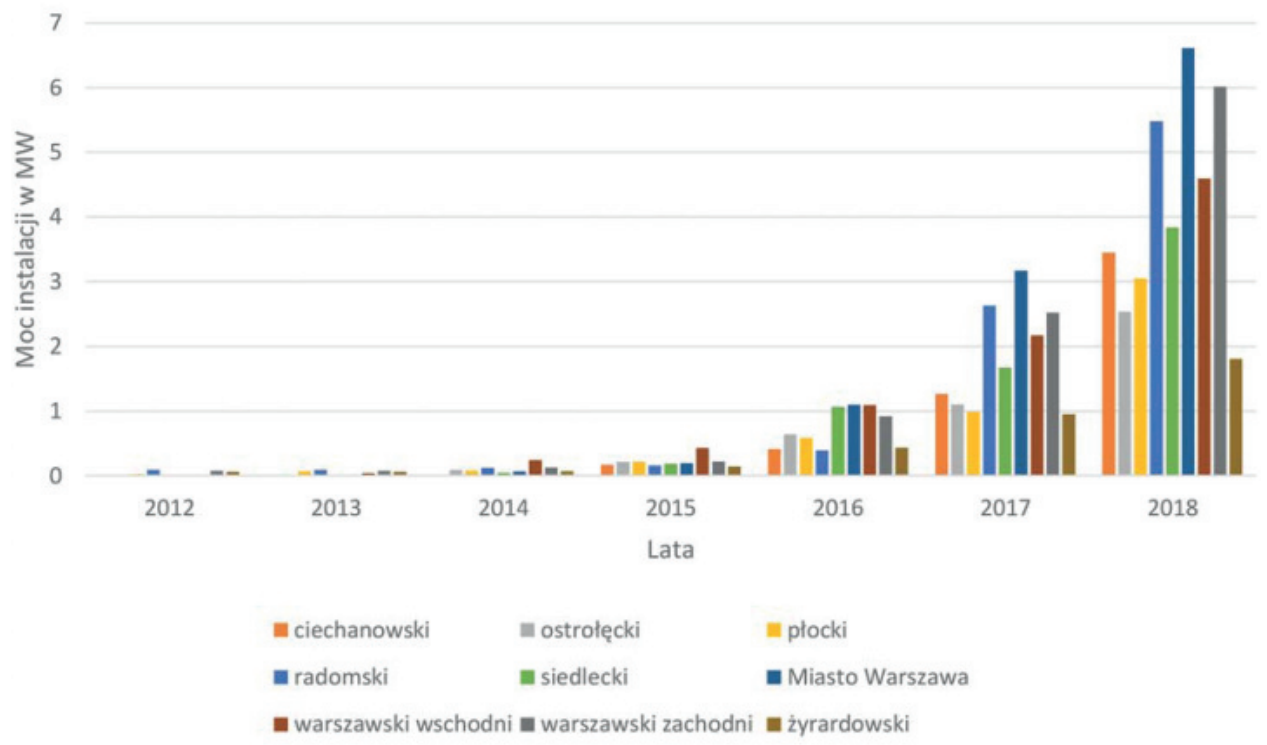

Ryc. 13. Łączna moc mikroinstalacji OZE pracujących w sieciach dystrybucyjnych niskiego napięcia w podregionach województwa mazowieckiego w latach 2012-2018

Źródło: opracowanie własne MBPR na podstawie danych uzyskanych w badaniu ankietowym gmin

Tabela 6. Mikroinstalacje OZE przyłączone do sieci dystrybucyjnych niskiego napięcia w podregionach województwa mazowieckiego - stan na 31.12.2018 r.

\begin{tabular}{|c|l|l|l|l|}
\hline Lp. & Podregion & $\begin{array}{l}\text { Lączna moc } \\
\text { mikroinstalacji } \\
\text { OZE [MW] }\end{array}$ & $\begin{array}{l}\text { Liczba } \\
\text { mikoinstalacji } \\
\text { OZE [szt] }\end{array}$ & $\begin{array}{l}\text { Średnia moc } \\
\text { mikroinstalacji [kW] }\end{array}$ \\
\hline 1. & ciechanowski & 3,446 & 527 & 6,54 \\
\hline 2. & ostrołęcki & 2,524 & 365 & 6,93 \\
\hline 3. & płocki & 2,505 & 494 & 6,16 \\
\hline 4. & radomski & 5,480 & 1044 & 5,25 \\
\hline 5. & siedlecki & 3,836 & 794 & 4,83 \\
\hline 6. & miasto Warszawa & 6,613 & 1152 & 5,74 \\
\hline 7. & warszawski wschodni & 4,585 & 647 & 7,1 \\
\hline 8. & warszawski zachodni & 6,015 & 936 & 6,42 \\
\hline 9. & żyrardowski & 2,538 & 253 & 7,15 \\
\hline & Region ogółem & 37,542 & 6212 & 6,01 \\
\hline
\end{tabular}

Źródło: opracowanie własne MBPR na podstawie danych uzyskanych w badaniu ankietowym gmin 
Tabela 7. Udział procentowy energii elektrycznej wytworzonej w mikroinstalacjach OZE przyłączonych do sieci dystrybucyjnych w ogólnym zapotrzebowaniu podregionów na energię niskiego napięcia - stan na 31.12.2018 r.

\begin{tabular}{|c|l|l|l|l|c|}
\hline Lp. & Podregion & $\begin{array}{l}\text { Roczne } \\
\text { zapotrzebowanie } \\
\text { na energię } \\
\text { nN [MWh] }\end{array}$ & $\begin{array}{l}\text { Lączna moc } \\
\text { mikoinstalacji } \\
\text { OZE [MW] }\end{array}$ & $\begin{array}{l}\text { Roczna } \\
\text { produkcja } \\
\text { energii } \\
\text { mikoinstalacji } \\
\text { OZE [MWh] }\end{array}$ & $\begin{array}{l}\text { Udział } \\
\text { procentowy } \\
\text { energii } \\
\text { OZE [\%] }\end{array}$ \\
\hline 1. & ciechanowski & 526365 & 3,446 & 3101 & 0,59 \\
\hline 2. & ostrołęcki & 592168 & 2,524 & 2272 & 0,38 \\
\hline 3. & płocki & 518676 & 2,505 & 2255 & 0,43 \\
\hline 4. & radomski & 941190 & 5,480 & 4932 & 0,52 \\
\hline 5. & siedlecki & 649062 & 3,836 & 3452 & 0,52 \\
\hline 6. & $\begin{array}{l}\text { miasto } \\
\text { Warszawa }\end{array}$ & 2956767 & 6,613 & 5952 & 0,20 \\
\hline 7. & $\begin{array}{l}\text { warszawski } \\
\text { wschodni }\end{array}$ & 984955 & 4,585 & 4127 & 0,42 \\
\hline 8. & $\begin{array}{l}\text { warszawski } \\
\text { zachodni }\end{array}$ & 927440 & 6,015 & 5414 & 0,58 \\
\hline 9. & żyrardowski & 392347 & 2,538 & 2284 & 0,58 \\
\hline & Region ogółem & 8488970 & 37,542 & 33788 & 0,40 \\
\hline
\end{tabular}

Źródło: opracowanie własne MBPR na podstawie danych uzyskanych w badaniu ankietowym gmin

$\mathrm{Na}$ bazie szczegółowych danych uzyskanych w ankietowaniu gmin podregionu siedleckiego, wyliczono średnie zapotrzebowanie na energię elektryczną niskiego napięcia przypadające na statystycznego mieszkańca gmin: miejskiej, miejsko-wiejskiej i wiejskiej. Było to odpowiednio: 1,663 MWh/rok, 1,306 MWh/rok i 1,545 MWh/rok. Przyjęto również uogólniające założenie, iż wartości wyliczone dla przeanalizowanych szczegółowo gmin podregionu siedleckiego można uznać jako zbliżone do rzeczywistych, odpowiadających sobie typów pozostałych gmin województwa. Na bazie założenia i na podstawie publikowanych przez GUS danych o liczbie mieszkańców gmin, wyliczono dla podregionów (tabela 7) i gmin (ryc. 14) województwa szacunkowy udział energii elektrycznej wytworzonej przez mikroinstalacje OZE w ogólnym zużyciu energii elektrycznej niskiego napięcia. Uzyskane wyniki potwierdzaja, iż udział ten jest zbliżony w prawie wszystkich podregionach (od $0,42 \%$ do $0,59 \%) z$ wyjątkiem podregionu Warszawa $(0,2 \%)$, w którym warunki rozwoju mikroenergetyki i specyfika sektora elektroenergetycznego są zdecydowanie inne niż w pozostałych jednostkach statystycznych województwa mazowieckiego. 
W odniesieniu do gmin, wystąpiły znacznie większe rozpiętości stopnia rozwoju mikroenergetyki, albowiem przodujące $\mathrm{w}$ tej dziedzinie jednostki osiągnęły wskaźniki na poziomie znacznie wyższym - gmina Stoczek w podregionie siedleckim zanotowała rekordową wartość - 6,36\%. Powyżej 1\% osiągnęło 56 gmin (17,2\%) województwa. Wyraźnie powyżej średniej wojewódzkiej $(0,4 \%)$ uplasowało się 71 gmin $(22,6 \%)$, w okolicach średniej 115 jednostek(36,6\%), znacznie poniżej 55 (17,5\%). Pozostałe 19 (6,1\%) gmin nie miało, wg stanu na 31.12. 2018 r., ani jednej mikroinstalacji przyłączonej do sieci dystrybucyjnej niskiego napięcia.

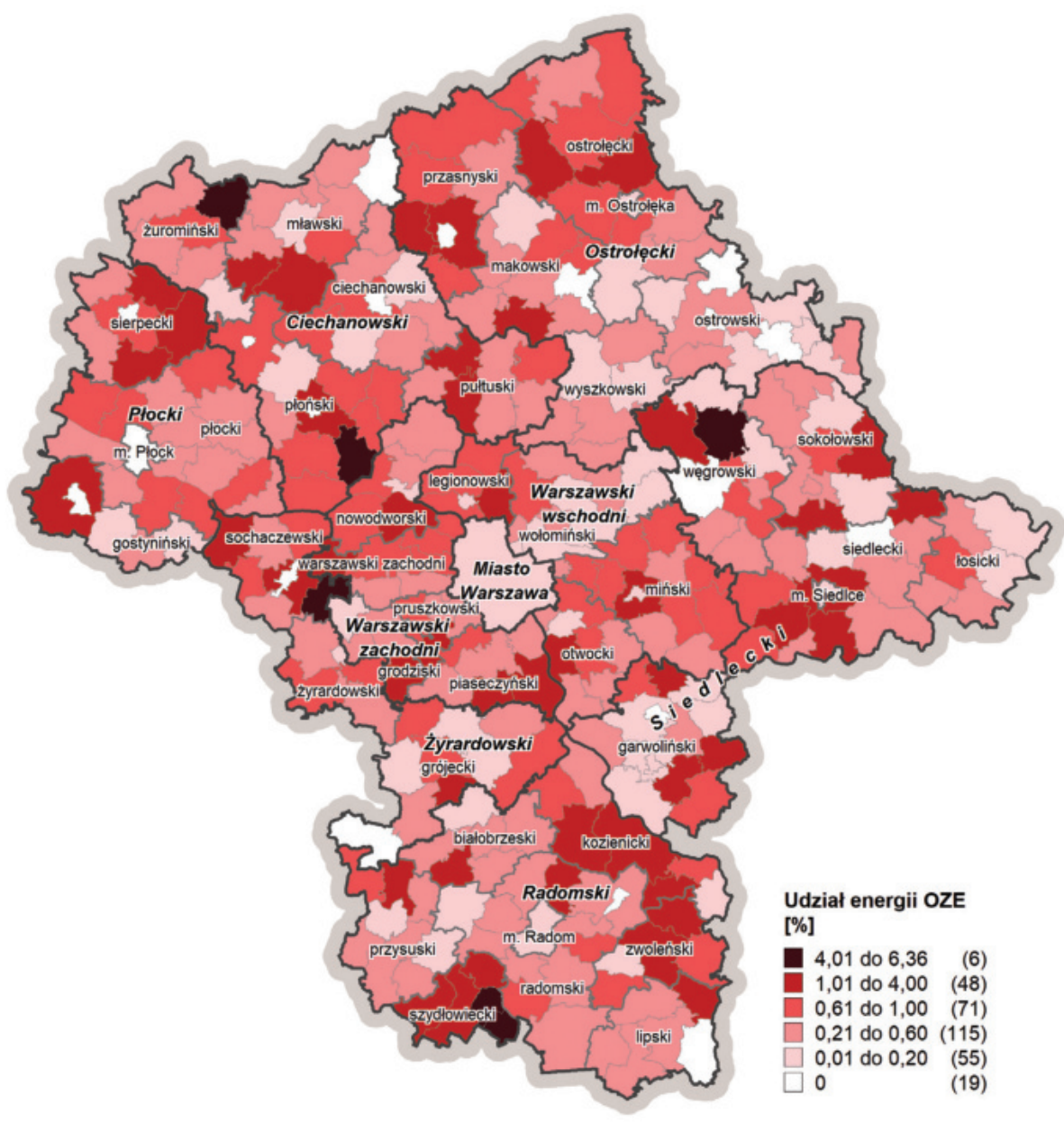

Ryc. 14. Udział energii elektrycznej wytworzonej w mikroinstalacjach OZE przyłączonych do sieci dystrybucyjnych w ogólnym zapotrzebowaniu gmin regionu na energię niskiego napięcia - stan na 31.12.2018 r.

Źródło: opracowanie własne MBPR na podstawie danych uzyskanych w badaniu ankietowym gmin 
Interesującą z technicznego punktu widzenia jest analiza struktury mikroinstalacji zainstalowanych łącznie $\mathrm{w}$ regionie w podziale na zakresy mocy. Pod względem liczebności (ryc. 15) i mocy sumarycznej (ryc. 16) dominują źródła o mocach w zakresie od $4 \mathrm{~kW}$ do $6,9 \mathrm{~kW}$, a więc odpowiednich dla średnich gospodarstw domowych, małych gospodarstw rolnych lub najmniejszych firm. Są to odbiorcy energii elektrycznej, których średnie roczne zapotrzebowanie zawiera się w przedziale 3,5-6,5 MWh/rok. Średnia wartość mocy statystycznej mikroinstalacji $\mathrm{w}$ regionie wynosi 6,01 kW, przy czym: najmniejsza - 4,83 kW w siedleckim i największa - 7,1 kW w żyrardowskim.

liczba szt

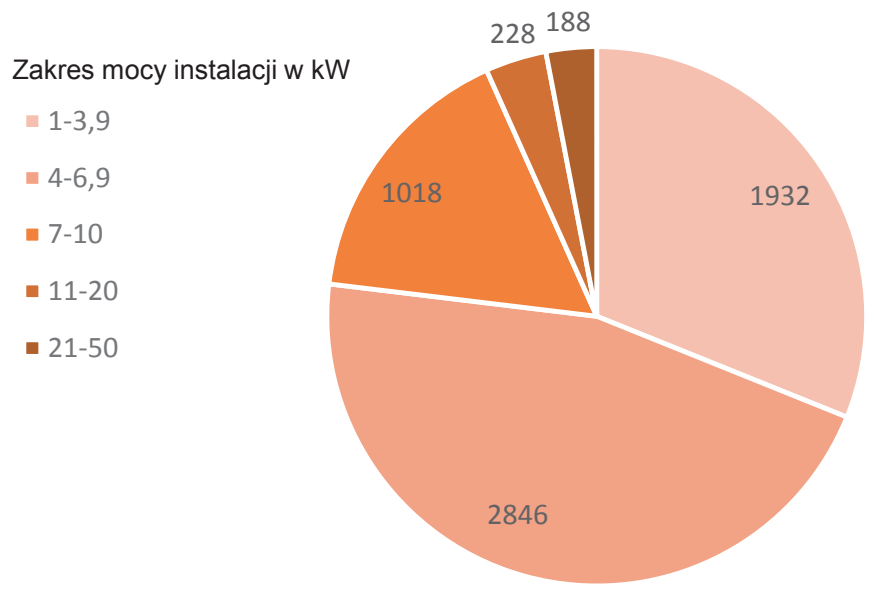

Ryc. 15. Struktura mikroinstalacji OZE przyłączonych do sieci dystrybucyjnych niskiego napięcia w województwie mazowieckim - stan na 31.12.2018 r.

Źródło: opracowanie własne MBPR na podstawie danych uzyskanych od operatorów sieci dystrybucyjnych 


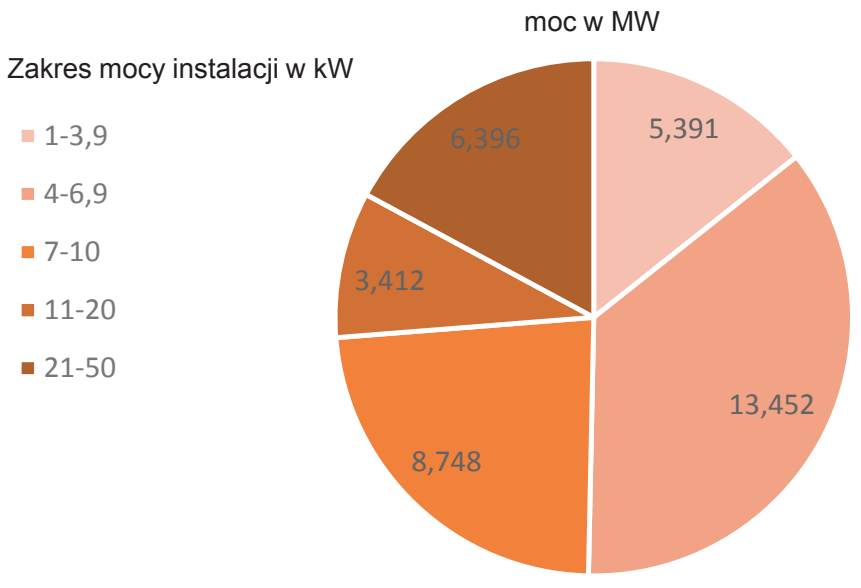

Ryc. 16. Udział energii elektrycznej wytworzonej w mikroinstalacjach OZE przyłączonych do sieci dystrybucyjnych w ogólnym zapotrzebowaniu gmin regionu na energię niskiego napięcia - stan na 31.12.2018 r.

Źródło: opracowanie własne MBPR na podstawie danych uzyskanych w badaniu ankietowym gmin

\section{Prognoza rozwoju segmentu mikroelektroenergetyki - 2020 r. Województwo mazowieckie}

Szacuje się, że łączna moc mikroinstalacji prosumenckich pracujących w sieciach dystrybucyjnych niskiego napięcia osiągnie w regionie wartość około 256,7 MW o potencjale wytwórczym rzędu 241 GWh. Prognozę oparto na założeniu, że tempo rozwoju segmentu mikroelektroenergetyki w skali regionu będzie zbliżone do tempa przewidywanego dla podregionu siedleckiego, w przypadku którego dysponowano znacznie szerszą bazą danych szczegółowych. Prognozowane na koniec 2020 r. ogólne zapotrzebowanie województwa na energię elektryczną niskiego napięcia wyniesie około 8746 GWh. Oznacza to, że może ono osiągnąć około 2,8\% udziału pochodzącej z mikroźródeł energii elektrycznej w ogólnej konsumpcji energii niskiego napięcia. Będzie to więc jedynie energia na poziomie około połowy strat technicznych występujących w dystrybucyjnych sieciach niskiego napięcia.

Również pochodzący z listopada 2019 r. zaktualizowany projekt rządowego dokumentu [Polityka energetyczna Polski do 2040 r.] nie przewiduje dla energetyki obywatelskiej (w tym mikroenergetyki prosumenckiej) znaczącej roli na poziomie krajowym. Zakłada się, że jej głównym zadaniem jest pokrywanie potrzeb indywidualnych prosumentów z możliwością wprowadzania nadwyżek energii do sieci dystrybucyjnych. 


\section{Podsumowanie}

Przeprowadzone analizy wykazały, że pomimo kilkuletniego okresu funkcjonowania na rynku energetycznym wyodrębnionego prawnie i technicznie segmentu mikroenergetyki, rzeczywiste tempo rozwoju tego segmentu jest znacznie mniejsze od prognozowanego. W przypadku łącznej mocy mikroźródeł energii elektrycznej zainstalowanej w województwie mazowieckim wg stanu na 31.12. 2018 r., stopień realizacji prognoz kształtował się $\mathrm{w}$ odniesieniu do tego roku na poziomie 16,2\%, natomiast dla podregionu siedleckiego był jeszcze mniejszy - osiągnął około 11,8\%. Pochodzące z 2015 r., robocze prognozy [Cieszkowski, Girczuk, Polak 2015] w zakresie udziału energii elektrycznej wytworzonej w mikrosegmencie OZE w ogólnej konsumpcji energii, przewidywały, że w 2018 r. wartość tego udziału wyniesie około $3-5,6 \%$, podczas gdy realna wartość osiągnęła: 0,4\% w województwie i $0,52 \%$ w podregionie siedleckim, przy rozpiętości: od 0,2\% w podregionie Warszawa do $0,59 \% \mathrm{w}$ podregionie ciechanowskim.

Ocena rzeczywistej roli, jaką mikroelektronergetyka prosumencka odgrywa w procesie transformacji energetycznej kraju oraz w konsekwencji również województwa mazowieckiego, wymaga odniesienia udziału produkcji energii elektrycznej nN wytworzonej w tym segmencie do całej energii elektrycznej z OZE wytworzonej i wprowadzonej do sieci na poziomie wszystkich napięć. W przypadku województwa mazowieckiego, wg danych GUS, w 2018 r. wyprodukowano w regionie ogółem 1450 GWh zielonej energii, przy czym udział mikroinstalacji kształtował się szacunkowo (brak jeszcze danych GUS w tym zakresie) na poziomie około $338 \mathrm{GWh}$, czyli około 23,3\% całego wolumenu energii z OZE.

Prowadzi to do wniosku, że udział segmentu mikroinstalacji OZE w ogólnej konsumpcji energii elektrycznej osiągnął w województwie mazowieckim znikomą wartość około 0,09\%. Prognozy dotyczące stanu przewidywanego na koniec 2020 r. wskazuja, że udział ten będzie na poziomie około $2,8 \% \mathrm{w}$ odniesieniu do niskiego napięcia i około $0,6-0,7 \%$ do całego sektora OZE.

Analizy wykazały, że jedynie 17,2\% gmin województwa mazowieckiego osiągnęło wskaźnik udziału wytworzonej w segmencie mikroinstalacji OZE energii elektrycznej nN w ogólnej konsumpcji energii tego napięcia, na poziomie od 1\% (maksymalnie 6,3\%). Natomiast 6,1\% gmin nie miało, wg stanu na 31.12.2018 r., ani jednej mikroinstalacji przyłączonej do sieci dystrybucyjnej niskiego napięcia.

W analizowanym podregionie siedleckim, w ramach inwestycji prowadzonych przez samorządy gminne, zrealizowano 57,7\% wszystkich mikroinstalacji do produkcji energii elektrycznej. Programy inwestycyjne zrealizowało jedynie $26,9 \%$ gmin, a realizację (w tym kontynuację) programów rozwojowych deklaruje 51,9\%. Aż 34,6\% samorządów gminnych nie zrealizowało i nie planuje programów rozwoju mikroelektroenergetyki prosumenckiej. W dziedzinie mikroprodukcji ciepła, działania inwestycyjne prowadziło $38,5 \%$ gmin podregionu, taki sam procent deklaruje realizację nowych lub kontynuację inwestycji prowadzonych. Całkowicie biernymi okazuje się 32,7\% jednostek samorządu terytorialnego, które nie wykonały i nie planują rozwoju mikroenergetyki cieplnej. 
Jak wynika z przeprowadzonych analiz, wysokość dochodów gmin podregionu siedleckiego wywiera pewien wpływ na ich politykę klimatyczno-energetyczną, aczkolwiek nie można uznać tego wpływu za przesądzający, bowiem wśród 7 gmin o najwyższych efektach inwestycyjnych, 1 należy do grupy o dochodach wysokich, 5 średnich i 1 najniższych. W pozostałych grupach dochodowych, czyli dochodów średnich i najniższych, również nie wystąpiły jednoznaczne zależności stopnia rozwoju mikroenergetyki od wysokości tych dochodów.

Stosunkowo wysoki, wynoszący 84,6\% wskaźnik aktywności planistycznej gmin, jak również podobny odsetek $(85,2 \%)$ jednostek o dużym i średnim stopniu zainteresowania mieszkańców problematyką energetyki lokalnej, nie przełożył się w podobnym stosunku na uzyskane efekty inwestycyjne, bowiem tylko 48,2\% gmin wykonało inwestycje w obszarze mikroenergetyki.

Wnioski

1. Realny rozwój segmentu mikroenergetyki prosumenckiej przebiega znacznie wolniej niż prognozowany. Mało sprzyjające rozwojowi były funkcjonujące do 2018 r. realia ekonomiczne. Poziom wsparcia dla prosumentów, ceny instalacji wytwórczych, nie gwarantowały akceptowanego społecznie okresu zwrotu nakładów inwestycyjnych.

2. Wprowadzone w 2019 r. istotne zmiany legislacyjne włączają w krąg prosumentów mikro, małe i średnie przedsiębiorstwa, spółdzielnie energetyczne. Mają one za zadanie, łącznie z wdrażanymi sukcesywnie w tym roku rządowymi instrumentami i programami organizacyjno-ekonomicznymi, znacznie przyspieszyć rozwój mikroenergetyki prosumenckiej.

3. Zdaniem autora, przełom nastąpi wówczas, gdy przy istotnym wzroście cen energii, jednostkowe koszty produkcji energii elektrycznej w systemie prosumenckim spadną poniżej cen zakupu energii z sieci dystrybucyjnych - prognozuje się, że będą to lata 2021-2022.

4. Na podstawie aktualnego stanu wiedzy o stopniu rozwoju mikroelektroenergetyki prosumenckiej w województwie mazowieckim oraz o lokalnych i krajowych uwarunkowaniach tego rozwoju, może ono na koniec 2020 r. osiągnąć wskaźnik udziału wyprodukowanej w tym segmencie energii w ogólnej konsumpcji energii $\mathrm{nN}$ na poziomie około 2,8\% (podregion siedlecki 3,6\%), natomiast perspektywa roku 2030 będzie możliwa do wstępnej prognozy dopiero około 2023-2024 r.

5. Jako przyczyny braku aktywności lub małego zakresu inwestycji w obszarze mikroenergetyki lokalnej, ankietowane gminy wymieniają brak funduszy własnych i zbyt małą pulę środków zewnętrznych, w tym przeznaczonych na realizację RPOWM 2014-2020, jednak zdaniem autora artykułu w grę wchodzą jeszcze istotne czynniki subiektywne, w tym brak wykwalifikowanych kadr zdolnych skutecznie prowadzić duże i specjalistyczne programy inwestycyjne, brak szerokiej akceptacji społecznej dla wydatkowania środków publicznych na ten cel i finansowego udziału mieszkańców w inwestycjach. 
6. Najważniejszą barierą techniczno-ekonomiczną jest obecnie problem magazynowania energii, jego rozwiązanie zmieni kształt całego sektora elektroenergetycznego, będzie to jednak odległa perspektywa kilkunastu-kilkudziesięciu lat.

7. Ekonomiczne i efektywne wykorzystanie zdolności lokalnych sieci dystrybucyjnychdo przyłączania mikroźródeł energii wymaga nawiązania ścisłej współpracy inwestorów (szczególnie gmin) z operatorami systemu energetycznego.

\section{Literatura}

Cieszkowski Z., 2019, Study of the development of prosumer microgeneration in the Siedlce subregion, MAZOWSZE Studia Regionalne, 30, Mazowieckie Biuro Planowania Regionalnego, Warszawa, s. 55-83.

Cieszkowski Z., 2018, Renewable sources of electricity in the Mazovia region, MAZOWSZE Studia Regionalne, 26, Mazowieckie Biuro Planowania Regionalnego, Warszawa, s. 61-87.

Cieszkowski Z., Girczuk J., Polak E., 2015, Rozwój energetyki opartej na źródłach odnawialnych w województwie mazowieckim - stan i wyzwania, MAZOWSZE Analizy i studia, 44, Mazowieckie Biuro Planowania Regionalnego, Warszawa.

Cieszkowski Z., 2004, Ocena stopnia zaawansowania procesu modernizacji wiejskich sieci elektroenergetycznych na terenach ZEWT S.A. Analiza dla potrzeb opracowań planistycznych, COSiW SEP, II Ogólnopolska Konferencja ETW, Materiały Konferencyjne, Jachranka.

Krajowy plan działania w zakresie energii ze źródeł odnawialnych - dokument przyjęty przez Radę Ministrów 7 grudnia $2010 \mathrm{r}$.

Krajowy Plan Rozwoju Mikroinstalacji Odnawialnych Źródeł Energii do roku 2030, 2015, Instytut Energetyki Odnawialnej, Warszawa.

Określenie potencjału energetycznego regionów Polski w zakresie odnawialnych źródeł energii wnioski dla Regionalnych Programów Operacyjnych na okres programowania 2014-2020, 2011, Instytut Energetyki Odnawialnej na zlecenie Ministerstwa Rozwoju Regionalnego, Warszawa.

Polityka energetyczna Polski do 2030 roku - dokument przyjęty przez Radę Ministrów w dniu 10 listopada 2009 r. (M.P. z 2010 r. nr 2, poz.11).

Polityka energetyczna Polski do 2040 r. - strategia rozwoju sektora paliwowo-energetycznego (PEP2040), projekt - wersja 8.11.2019, Ministerstwo Energii, Warszawa.

Plan Zagospodarowania Przestrzennego Województwa Mazowieckiego - Uchwała Nr 22/18 Sejmiku Województwa Mazowieckiego z dnia 19 grudnia 2018 r. (Dz.Urz. Woj. Maz. z 2018 r. poz. 13180).

Program możliwości wykorzystania odnawialnych źródeł energii dla Województwa Mazowieckiego, Uchwała Nr 208/06 Sejmiku Województwa Mazowieckiego z dnia 9 października 2006 r. 
Strategia Rozwoju Województwa Mazowieckiego do 2030 roku. Innowacyjne Mazowsze, Uchwała Nr 158/13 Sejmiku Województwa Mazowieckiego z dnia 28 października 2013 r.

Straty energii elektrycznej w sieciach elektroenergetycznych, 2018, Polskie Towarzystwo Przesyłu i Rozdziału Energii Elektrycznej, VIII konferencja naukowo-techniczna 21-22 marca, Wrocław.

Ustawa z dnia 10 kwietnia 1997 r. Prawo energetyczne (Dz.U. z 2018 r., poz. 755 z późn. zm.) Ustawa z dnia 20 maja 2016 r. o inwestycjach w zakresie elektrowni wiatrowych (Dz.U. z 2016 r., poz. 961).

Ustawa z dnia 22 czerwca 2016 r. o zmianie ustawy o odnawialnych źródłach energii oraz niektórych innych ustaw (Dz.U. z 2016 r. poz. 925).

Ustawa z dnia 7 czerwca 2018 r. o zmianie ustawy o odnawialnych źródłach energii oraz niektórych innych ustaw (Dz.U. z 2018 r. poz. 1276).

Ustawa z dnia 19 lipca 2019 r. o zmianie ustawy o odnawialnych źródłach energii oraz niektórych innych ustaw (Dz.U. z 2019 r. poz. 1524). 


\section{Study of the microgeneration development in the Siedlce subregion including basic effects of electricity microgeneration development in other subregions of Mazovia Voivodeship}

\section{ABSTRACT}

The article presents the material results of RES energy use in the microgeneration of power and heat in the Siedlce subregion. The region, selected for detailed research and analyses, includes 52 municipalities - 16,5\% of all municipalities of Mazovia Voivodeship. The influence of national legal conditions, statutory support system, planning and organizational activities of self-governments of the voivodship and the municipalities on the development of microgeneration (including prosumer microgeneration) was investigated. The analyses at the subregional level were conducted using the detailed information obtained from the survey conducted in the municipalities, data from (...) energy companies and the Central Statistical Office [GUS]. Basic local conditions were analysed, i.e. economic (municipal incomes), technical (municipal energy profiles, conditions of distribution networks), construction and environmental. Numerous positive factors influencing the development of the sector were highlighted, but real limitations were also clearly indicated. At the moment, there are no specialized and detailed publications on the practical results of the development of the microgeneration sector at the Mazovian municipalities level. This article is intended to fill this gap, whereas in subregions of the voivodship other than Siedlce, only a preliminary estimated analysis in the electricity microgeneration sector was possible, based on available data. An author's attempt was made to determine the projected share of this energy sector in the share of Mazovia Voivodeship in achieving national RES targets in the 2020-2030 period; it was based on the conducted analyses and the latest legislative and organizational actions of the government aimed at facilitating the development of prosumer microgeneration.

Keywords: renewable energy sources (RES), prosumer, environmental and energy policy, microinstallation, photovoltaic installation, solar collector, heat pump

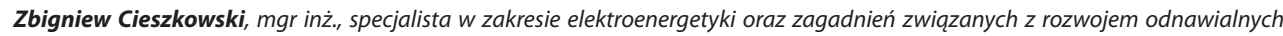
źródeł energii, pracownik Oddziału Terenowego w Siedlcach Mazowieckiego Biura Planowania Regionalnego w Warszawie. Zbigniew Cieszkowski, MSc Eng, a specialist in the area of electricity and renewable energy development, an employee of the Field Branch in Siedlce of the Mazovian Office for Regional Planning in Warsaw. 